\title{
Is Banning Enough? The Intricacy Inherent to Marine Mammal Conservation
}

\author{
Ilja Richard Pavone
}

(Received 20 April 2018; accepted 30 October 2018)

\begin{abstract}
Declining populations of marine mammals have led to growing concern about their conservation. As a result, a series of specific conservation measures have been put in place (bans on hunting and trading, establishment of protected marine areas). Such rules, although restoring the populations of some species of marine mammals, have nevertheless failed to protect them from the most challenging threat to their survival: the bycatch of non-target species. Accordingly, this Article highlights gaps within fisheries law, clarifying the efficacy of existing norms on the protection of the most endangered marine species of marine mammals, with a particular focus on cetaceans, from over-exploitation.

To this aim, the Article explores the peculiar norms developed by treaties of global and regional scope and the European Union (EU) with reference to specific species, including whales, seals, small cetaceansreferred to as direct protection. The Article then proceeds to an analysis of fisheries law that addresses, in an incidental manner, marine mammal protection-referred to as indirect protection.

The Article is based on the assumption that measures simply banning hunting or fishing, as envisaged by wildlife law, must necessarily be complemented by fisheries law-that is, Inter-regime linkages. Paradoxically, indirect protection can have a major impact in terms of improvement of both fish welfare and conservation; the problem lies in the fact that current fisheries law fails to provide an adequate response to bycatch. This Article proposes methods to improve fisheries law and also discusses whether the emerging concept of fish welfare can be an asset if included in fisheries rules; the Article ultimately contends that welfare issues must necessarily be part of future legal developments.
\end{abstract}

Keywords: Marine mammals; fish welfare; wildlife law; fisheries law

\section{A. Introduction}

Marine mammals are air breathers that have adapted themselves to live in the marine environment. ${ }^{1}$ The two major groups, cetaceans—-whales and dolphins—and pinnipeds—seals, sea lions, and walruses-are both directly and indirectly threatened by interaction with commercial

${ }^{*} \mathrm{PhD}$, Researcher of International Law, National Research Council of Italy (Rome), Professor of Environmental Law, Tuscia University (Viterbo). This research was carried out during a research stay at the Max Planck Institute for Comparative Public Law and International Law (Heidelberg) as Visiting Scholar in 2018 thanks to a research grant provided by DAAD (Deutscher Akademischer Austauschdienst). For their valuable suggestion and critical comments, I am indebted to Anne Peters, Zoë Hammatt, Guillaume Futhazar, Tom Sparks.

${ }^{1}$ Alexander Proelß, Marine Mammals, in Max Planck Encyclopedia of Public International LaW Vol. 6,1036 (Rüdiger Wolfrum ed., 2007); Marine Mammal Protection, NOAA Fisheries (2019) http://www.nmfs.noaa.gov/pr/species/ mammals/ (last visited May 10, 2019).

(C) 2019 The Author. Published by Cambridge University Press on behalf of the German Law Journal. This is an Open Access article, distributed under the terms of the Creative Commons Attribution licence (http://creativecommons.org/licenses/by/4.0/), which permits unrestricted re-use, distribution, and reproduction in any medium, provided the original work is properly cited. 
fisheries. ${ }^{2}$ Direct threats include fishing and hunting, while indirect threats consist of bycatch, illegal fishing, and illegal trade. Although they are not generally the direct target of fisheries, they are often victim of incidental capture in many parts of the world through bycatch in fishing gear. Furthermore, in some countries, marine mammals are still directly hunted for their skin and meat. Japan, Norway, and Iceland still practice whale hunting despite the international moratorium: Dolphins are slaughtered in Taiji, Japan; pilot whales are slaughtered in the Faroe Islands; and seals are skinned in Canada and Greenland.

The practice of fishing entails a high degree of violence. Wild fish caught in nets by fishing vessels are dumped onto the decks of ships, doomed to die of asphyxiation, or, as is often the case, used as living bait that remain hooked for hours. Still, others simply stay trapped in gill nets. All this happens in the total absence of any ethical reflection or legislation that address these problems. The issue is even more complicated with regard to cetaceans, that is, marine mammals that possess sophisticated cognitive capacities. ${ }^{3}$ In fact, because of their peculiar characteristics, vulnerability, high moral standing, and low economic value in most countries, marine mammals cannot be classified as fish and instead require different management approaches. ${ }^{4}$ Because most of them are in the category of endangered or threatened species, they are mostly protected by wildlife law, although fisheries law is also relevant and rather crucial to any comprehensive protective effort. In fact, bycatch-or accidental catch-and non-target catch-the unintentional capture of marine mammals that are retained on board for consumption or sale ${ }^{5}$-are the major global threats to marine mammal conservation. Bycatch and non-target catch constitute the main drivers of extinction of the Yangzte River dolphin in China and are currently pushing the Vaquita Porpoise in Mexico towards extinction. ${ }^{6}$ These fishing practices also have additional wide-reaching welfare consequences. ${ }^{7}$ Entanglement in fishing gear causes suffering and pain in marine mammals. Asphyxiation and eventual death through drowning are considered to be highly stressful

\footnotetext{
${ }^{2}$ IUCN, https://www.iucnredlist.org/species/12119/50362206, (last visited May 10, 2019) (classifying six species or populations as critically endangered, and one of these, the Yangtze River dolphin (Lipotes vexillifer), or Baiji, is considered extinct, and another nine are considered endangered of which nine are threatened by fisheries bycatch).

${ }^{3}$ Scientists have recognized cognitive capacities in several of the ninety species of cetaceans, thus making them more similar to Great Apes than to other living marine species. Lori Marino, Cetacean Cognition, in The Oxford Handbook OF AnimaL Studies 228, 228 (Linda Kalof ed., 2017); M.L. Campbell \& V.G Thomas, Protection and Conservation of Marine Mammals in Canada: A Case for Legislative Reform, 7 OCEAN \& COASTAL L.J. 221, 225 (2001).

${ }^{4}$ Marine mammals are animals that live in a marine or aquatic environment and are characterized by four major common elements. They breathe air, are warm-blooded, give birth to their offspring, and the females feed their cubs with their own milk. They include three taxonomic orders: Cetacea (whales, dolphins, and porpoises); Pinnipedia (seals); and Sirenia (manatees and dugongs). The polar bear (Ursidae), a marine carnivore, is also classified as a marine mammal. The 1972 US Marine Mammals Protection Act, later modified in 1994, defines marine mammals as "any mammal which is morphologically adapted to the marine environment (including sea otters and members of the orders Sirenia, Pinnipedia and Cetacea), or primarily inhabits the marine environment (such as the polar bear)." Marine Mammal Protection Act of 1972, 16 U.S.C. $\$ 1362$ (2018). Although polar bears are considered marine mammals, this study does not address them. They are protected through the 1973 Agreement on the Conservation of Polar Bears—signed by Canada, Greenland via Denmark, Norway, the former Soviet Union, and the United States. Id. $₫ 1368$.

${ }^{5}$ Martin A. Hall, On Bycatches, 6 Rev. In Fish Biology \& Fisheries 319 (1996).

${ }^{6}$ Whaling, bycatch, entanglement in fishing gears, and habitat depletion are the main threats to their conservation. Other threats-highlighted by the Report of 67a Scientific Committee (SC) meeting of the IWC held in Bled, Slovenia from May 9-21, 2017-are ship strikes, marine debris, climate change, chemical and noise pollution, harmful algal blooms, and captivity. See InTERnational Whaling Commission, https://iwc.int/scientific-committee-report-published (last visited May 10, 2019).

${ }^{7}$ A report prepared by WWF-in collaboration with the Convention on Migratory Species and released on May 22, 2018 highlights that every year over 300,000 cetaceans die from suffocation or entanglement in fishing gear such as gillnets. Russell leaper \& Susannah Calderan, Review of Methods Used to Reduce Risks of Cetacean Bycatch and Entanglements: CMS Technical Series Publication No. 38 (2018), https://www.cms.int/sites/default/files/ CMS_Report_042918_web_pages.pdf.
} 
for cetaceans. ${ }^{8}$ Indeed, several studies have reported that the death from suffocation in cetaceans ranges from three to five and half minutes in harbor porpoises to over sixty minutes in sperm whales. ${ }^{9}$ Despite growing concern about welfare implications of marine mammal bycatch in large scale or industrial high seas fisheries, fisheries law and conservation treaties (ICRW, CITES, CMS) have failed to adequately address this question. ${ }^{10}$

Currently, wildlife law has a single species approach-affording special protection to species threatened with extinction-with rules that focus on conserving populations or ecosystems, rather than treating individual conditions or suffering. Concern over the welfare of animals tends to only set in when humans catch and extract wild animals from their natural environments-or, as is the case practically speaking, when wild animals become entangled in fishing gear.

Against this background, this Article will explore new approaches to conservation of cetaceans in international and European law. To this aim, this Article analyzes the effectiveness of rules that provide direct and indirect protection, respectively wildlife law and fisheries law; it also considers which set of rules is more effective in marine mammal conservation.

Part B addresses substantive rules within wildlife law that provide direct protections for whales, dolphins, and seals or establish specific regions prohibiting hunting and whaling. Accordingly, Part B focuses on the International Convention on the Regulation of Whaling, CITES, treaties and programs of regional scope such as ASCOBANS, and EU rules protecting cetaceans and seals. Part $\mathrm{C}$ analyzes the existing legal rules that address the issue of bycatch-for example, the US Marine Mammal Protection Act, RFMOs' actions against bycatch, and EU regulations on bycatch.

This Article concludes that an appropriate conservation policy must move from the concept of sustainable utilization towards sustainable use and conservation in order to reach coexistence between the human and marine species. Measures within the latter paradigm include, for example, establishing large marine reserves in the high seas or prohibiting the use of certain kinds of nets. This more sophisticated legal regime must include welfare strategies in support of fisheries policies that consider cetaceans as animals possessing high levels of cognition. In this sense, avoiding the commercial exploitation of cetaceans must fall second to their continued survival. This Article thus maintains that banning-measures under wildlife law are not enough and necessarily must be complemented by efficient fisheries law measures against bycatch and illegal fishing. Consequently, inter-regime linkages, as the adequate interplay between wildlife law and fisheries management law, is the key to the achieving the appropriate balance. ${ }^{11}$

\footnotetext{
${ }^{8}$ Sarah J. Dolman \& Michael J. Moore, Welfare Implications of Cetacean Bycatch and Entanglements, in MARINE MAMMALS Welfare 41, 42 (Andrew Butterworth ed., 2017) (including cetaceans in the same category as primates because they are highly sentient and sensitive mammals).

${ }^{9}$ Carl D. Soulsbury, Graziella Iossa \& Stephen Harris, The Animal Welfare Implications of Cetacean Deaths IN FISHERIES 26 (2008), http://www.wdcs.co.uk/media/submissions_bin/wdcs_bycatchreport_2008_full.pdf.

${ }^{10}$ Animal welfare is a concept widely diffused in modern animal law and is the foundation of growing animal welfare legislation which addresses the protection of lab, farm, and companion animals—global animal law. See ANIMAL LAw: Reform or Revolution? (Anne Peters, Saskia Stucki \& Livia Boscardin eds., 2015); Anne Peters, Global Animal Law: What It is and Why We Need It, 5 Transnat'L. EnVTL. L. 9 (2016). Comparatively, the issue of fish welfare is a recent and often neglected issue. Felicity Huntingford, Colin Adams, Victoria Braithwaite \& Sunil Kadri, Current Issues in Fish Welfare, 2 J. Fish Biology 332 (2006) (discussing the issue of fish welfare first). This study noted that fishing and aquaculture are amongst the human activities that have major negative impacts on the welfare of both targeted and accidentally caught species, such as dolphins, whales, sea turtles, and sharks. Fish welfare is considered to be the absence of suffering, though this theory does not clarify the unresolved and controversial issue in the scientific debate about awareness in marine vertebrates-that is, do they suffer when physically injured or confined? See VICTORIA Braithwaite, Do Fish Feel Pain? (2010).

11 "Inter-regime linkages" is a term coined by Young to address the "interplay among distinguishable, institutional arrangements.” See Oran R. Young, Institutional Linkages in International Society: Polar Perspectives, 2 GloB. GovernANCE 1 (1996); Solène Guggisberg, The Use of CITES for Commercially-exploited Fish Species: A Solution to Overexploitation AND IlLEGAL UNREPORTED AND UNREgUlATED FisHING? 253 (2016) (advancing the necessity of the interplay between CITES and RFMOS in the field of fisheries management); MARgaret A. Young, Trading Fish, SAving Fish: The Interaction
} 


\section{B. Direct Protection}

\section{Wildlife Protection}

The wildlife conservation regime is relevant to the conservation of marine species listed in the IUCN Red List of endangered and threatened species. ${ }^{12}$ Nevertheless, this regime only serves as a complement to the fishing management regime, because it exclusively addresses species that are already or almost threatened. The regime aims to prohibit illegal behavior that leads to or can lead a species to the brink of extinction. This includes prohibitions against habitat destruction or illegal trade, rather than prohibitions against specific methods of fishing or whaling or other practices that have a negative impact on the welfare of animals, like seal skinning. Therefore, wildlife law does not intend to ban finning, whaling, or hunting, or address the main causes of stock depletion, such as bycatch, or manage strategies of recovery after a harvestdriven depletion.

Wildlife law generally establishes a blanket prohibition against commercial trade or hunting of heavily threatened species but allows trade or hunting in a regulated manner for species that are not yet at risk of extinction. ${ }^{13}$ On the contrary, fisheries law has the main goal of setting fishing quotas that ensure sustainable uses of the biological resources of the sea.

\section{The International Legal Regime on Whale Hunting}

Cetaceans, and in particular whales, are strictly protected under international law by a set of rules banning whaling - the 1946 International Convention for the Regulation of Whaling (ICRW) ${ }^{14}$ and trade and commerce of specimens of such species- the 1973 Convention on International Trade in Endangered Species of Wild Fauna and Flora (CITES). Indeed, ICRW and CITES form the "international legal regime on whale hunting."15

\section{The Whaling Convention}

Due to the potential economic value of cetaceans and, in particular, of whales, whale hunting has an ancient tradition. With the development of new technologies, whaling grew in an uncontrolled manner during the first half of the twentieth century, resulting in a drastic decline of whale populations. The demand for international regulation of whale hunting consequently increased and eventually led to the adoption of the ICRW's successors-the 1931 and 1937 conventions on the regulation of whaling. ${ }^{16}$ Comparatively, the ICRW is a conservation treaty that does not aim to abolish whale hunting, but rather, exemplify a classical resource exploitation regime that echoes the classification of Dupuy and Viñuales, ${ }^{17}$ which was drafted with the scope of regulating whaling in order to ensure sustainable exploitation and to avoid excessive stock depletion. Due to the steady drop of the whale population, the International Whaling Commission (IWC $)^{18}$ shifted towards a more conservationist-oriented approach with the decision to establish a moratorium on whaling in 1982 - that is, a zero catch limit—in order to reinforce whale preservation, effective

BETWEen REgimes IN INTERNATIONAL LAW (2011) (discussing the necessity of a major cooperation between different legal regimes).

${ }^{12}$ IUCN, supra note 2.

${ }^{13}$ S. M. Wells \& J. G. Barzdo, International Trade in Marine Species: Is CITES a Useful Control Mechanism? 19 COASTAL MGMT., 135 (1991).

${ }^{14}$ The ICRW was adopted in Washington, D.C., on December 2, 1946, and entered into force on November 10, 1948.

${ }^{15}$ Ed Couzens, Whales and Elephants in International Conservation LaW and Politics: A Comparative Study 155 (2014).

${ }^{16}$ Kurkpatrick Dorsey, Whales and Nations: Environmental Diplomacy on the High Seas (2013) (explaining the history of whaling and the diplomatic process behind the adoption of these treaties).

${ }^{17}$ Pierre-Marie Dupuy \& Jorge E. Viñuales, International Environmental LaW 160 (2015).

${ }^{18}$ Article III of the Convention established the International Whaling Commission (IWC), which is an intergovernmental organization in charge of the conservation and management of whale resources. 


\section{from the 1985 to 1986 season $^{19}$-thus transforming de facto the ICRW into a conservation} treaty. ${ }^{20}$

The moratorium represents an advance on conservation efforts through its ban on trade or any exploitation activity. Studies have shown that measures like the moratorium that ban fishing, trade, and exploitation have resulted in a significant increase in whale populations as well as in the populations of other marine mammals. ${ }^{21}$ Therefore, marine mammals have benefited from the shift from resource-utilization policy towards conservation-oriented policy.

To elaborate, some populations from the Southern Hemisphere, like the Antarctic fur seal ${ }^{22}$ and the blue whale, have reached their estimated pre-exploitation abundance levels, ${ }^{23}$ while other marine mammals, like the South American sea lion (Otaria flavescens) are recovering after hunting cessation, notwithstanding only having attained $40 \%$ of the highest levels reached prior to commercial hunting. ${ }^{24}$ Norway and the Faroe Islands, traditionally whaling States, however, made use of the opt-out clause envisaged by Article V of the Whaling Convention; therefore, regardless of the criticism voiced by public opinion and environmental groups, their commercial whaling is lawful. ${ }^{25}$

Nevertheless, there is a big caveat to the zero catch limits for commercial whaling, which allows whaling countries to perpetuate their hunting policy. Given that the quota applies only to commercial whaling, whales can still be killed so long as it is for scientific purposes. Article VIII of the ICRW allows special exceptions for "scientific whaling" and aboriginal subsistence whaling. ${ }^{26}$ As is

\footnotetext{
${ }^{19}$ International Convention for the Regulation of Whaling, Dec. 2, 1946, 62 Stat. 1716 [hereinafter International Convention for the Regulation of Whaling]. Technically, the moratorium was set up by the adoption of Paragraph 10(e) of the ICRW's Schedule. The Schedule "forms an integral part of" the ICRW_Id. art. 1, para. 1._and stipulates that "regulations with respect to the conservation and utilization of whale resources." Id. art. 5, para. 1. Schedule Paragraph 10(e) states:

Notwithstanding the other provisions of paragraph 10, catch limits for the killing for commercial purposes of whales from all stocks for the 1986 coastal and the 1985/86 pelagic seasons and thereafter shall be zero. This provision will be kept under review, based upon the best scientific advice, and by 1990 at the latest the Commission will undertake a comprehensive assessment of the effects of this decision on whale stocks and consider modification of this provision and the establishment of other catch limits.

Proelß, supra note 1 , at 1036.

${ }^{20}$ Patricia Birnie, International Regulation of Whaling: From Conservation Whaling to Conservations of Whales AND REgUlations of Whale WATCHING (1985) (discussing the moratorium as not the only conservation measure adopted by IWC_-indeed, it designated two whale sanctuaries where every form of whaling is prohibited: the Indian Ocean Sanctuary and the Southern Ocean Sanctuary which covers the waters around Antarctica); Alexander Gillespie, The Southern Ocean Sanctuary and the Evolution of International Environmental Law, 15 INT'L. J. MARINE \& COASTAL L. 293 (2000).

${ }^{21}$ Heike K. Lotze, Joanna Mills Flemming \& Anna M. Magera, Critical Factors for the Recovery of Marine Mammals, 31 Conservation Biology 1301, 1310 (2017).

${ }^{22}$ Antarctic seals were led to the brink of extinction by excessive hunting pressure from the United States and United Kingdom. The 1972 Convention for the Conservation of Antarctic Seals-established within the Antarctic Treaty System - considered the continental and territorial waters of Antarctica as protected areas, where the hunting or collecting of seals or other marine mammals is strictly prohibited. By relieving intense hunting pressure, fur seals were able to proliferate again and overcome the pre-sealing population. Martin Holdgate, Convention on the Conservation of Atlantic Seals, ENCYCLOPEDIA of THE ANTARCTIC 293 (2007).

${ }^{23}$ Andrew D. Lowther, Antarctic Marine Mammals, Encyclopedia of Marine Mammals 27 (Bernd Würsig, J.G.M. Thewissen \& Kit M. Kovacs eds., 3d ed. 2018).

${ }^{24}$ To date, South American sea lions are classified by the IUCN Red List as "Least Concern." S. Cárdenas-Alayza, E. Crespo \& L. Oliveira, Otaria Byronia, The IUCN Red List of Threatened Species (2016), https://www.iucnredlist.org/species/pdf/ 61948292; see also María Alejandra Romero et al., Analysing the Natural Population Growth of a Large Marine Mammal After a Depletive Harvest, 7 SCI. REP. 1 (2017).

${ }^{25}$ Catches Taken: Under Objection or Under Reservation, INT'L WHALING COMM'N (2019), https://iwc.int/table_objection (last visited May 7, 2019); Malgosia Fitzmaurice, Whaling And InTERnational LAW 189 (2015); see also Vanessa Williams-Grey, End the Whale Hunts! Icelandic Fin Whaler Isolated as Public Mood Shifts, WDC (May 21, 2018), http:// us.whales.org/blog/2018/05/end-whale-hunts-icelandic-fin-whaler-isolated-public-mood-shifts (analyzing a change of attitude towards whaling by the same Icelanders).

${ }^{26}$ International Convention for the Regulation of Whaling, supra note 19, at art. 8 (allowing for the killing of whales "for purposes of scientific research subject to such restrictions as to number and subject to such other conditions as the Contracting Government thinks fit").
} 
well known, the scientific whaling loophole has fueled abuse perpetrated by Japan through its contested JARPA I and II programs that have allowed Japanese whaleboats to indiscriminately kill hundreds of whales under the guise of scientific research. As a consequence of the complaint against Japan presented by Australia with the support of New Zealand, the International Court of Justice condemned Japan and concluded that "the special permits granted by Japan for the killing, taking and treating of whales in connection with JARPA II are not 'for purposes of scientific research' pursuant to Article VIII, paragraph 1, of the 1946 Convention." 27 Nevertheless, despite the ICJ Judgement, Japan continues its highly controversial scientific whaling in international waters off the Southern Ocean, including in the Southern Ocean Whale Sanctuary, through the NEWREP-A program. ${ }^{28}$

Special permits issued by the Japanese government with reference to this scientific program violate IWC Resolutions 2014-5 and 2016-2, which requested governments not to issue further permits until the conclusion of an assessment study by the IWC's Scientific Committee. ${ }^{29}$ The 2017 Report of the Standing Working Group on Special Permit Programmes underlined, in particular, that Japan failed to comply with these IWC Resolutions, noting that lethal sampling remains unjustified, because "the proponent of NEWREP-NP has not provided sufficient scientific evidence that justifies the need for lethal sampling." ${ }^{30}$ It seems clear that in this case Japan breached its obligation to cooperate as reiterated in the Whaling Case, whereas the Court affirmed that "[the states] have a duty to co-operate with the IWC and the Scientific Committee. ... ."31

This event clearly shows that the main weakness of the IWC lies in the long-standing struggle between parties that contravene the commercial exploitation of whales-Australia, EU Member States, New Zealand, South American States, USA — and whaling States-Japan, Iceland, Norway. Australia, in particular, has assumed the leadership of the pro-conservation group within the IWC. ${ }^{32}$ The division between pro- and anti-whaling States was clearly witnessed during the $67^{\text {th }}$ IWC meeting-Florianopolis, Brazil, September 28, 2018-when a Japanese proposal aimed at putting an end to the moratorium on whaling was rejected..$^{33}$ On the contrary, another approved bid-sponsored by the anti-whaling block—reaffirmed the importance of maintaining the moratorium. ${ }^{34}$ In response to the rejection of its proposal by the anti-whaling camp, Japan formally

\footnotetext{
${ }^{27}$ Whaling in the Antarctic (Austl. v. Japan), Judgment, 2014 I.C.J. Rep. 226, 294, II 227 (Mar. 31); see also Brendan Gogarty \& Peter Lawrence, The ICJ Whaling Case: Missed Opportunity to Advance the Rule of Law in Resolving Science-Related Disputes in Global Commons? 77 HeIdelberg J. INT'L. L. 161 (2017) [hereinafter Austl. V. Japan] (providing a critical position on the ICJ Judgment).

${ }^{28}$ See Joint Statement Against Whaling, N.Z. ForeIGN AFF. \& TrADE (Dec. 18, 2017), https://www.mfat.govt.nz/en/mediaand-resources/ministry-statements-and-speeches/joint-statement-on-whaling/ (showing signatures by Argentina, Australia, Brazil, Chile, Costa Rica, the Dominican Republic, Ecuador, the European Union and its Member States, Mexico, New Zealand, Panama, Peru, and Uruguay_calling for Japan "to end lethal research in the Southern Ocean").

${ }^{29}$ I.W.C. Resolution 2014-5 on Whaling under Special Permit (Sept. 2014); see also id. at II 3 ("[T]hat no further special permits for the take of whales are issued under existing research programmes or any new programme of whale research."); see also I.W.C. Resolution 2016-2 on Improving the Review Process for Whaling under Special Permit (Oct. 2016).

${ }^{30}$ IWC/67/16 Report of the Standing Working Group on Special Permit Programmes, agenda item 14.5, p. 4 (Jul. 12, 2017), https://iwc.int/spw-scientific-review.

${ }^{31}$ Austl. v. Japan, 2014 I.C.J. at 257, II 83.

${ }^{32}$ Explanatory Statement Issued by Minister for the Environment, Environment Protection and Biodiversity Conservation Act 1999 (Cth) (Austl.).

${ }^{33}$ The Japanese proposal "Way Forward" was defeated because it obtained only twenty-seven votes in support, while fortyone States-led by anti-whaling States, such as Australia, Brazil, EU States, and the United States—voted against, and two abstained. The IWC Plenary Closes with Acknowledgment of Difficult Differences and Commitment to Mutual Respect, INT'L Whaling Comm'N (Sept. 14, 2018), https://iwc.int/day-five. Some developing countries—such as Cambodia, Laos, Kenya, Morocco, Nicaragua, Tanzania, and Pacific and Caribbean islands-voted in favor of the Japanese proposal. See Julia Jabour \& Lucy Smejkal, Japan at the International Whaling Commission, Austl. Outlook (Sept. 11, 2018), https://www. internationalaffairs.org.au/australianoutlook/japan-at-the-international-whaling-commission/.

${ }^{34}$ IISD Reporting Services, Florianopolis Declaration, 34 EARTH NEGOT. Bull. 10 (Sept. 17, 2018), http://enb.iisd.org/iwc/ 67/13sep.html. The Declaration was supported by, inter alia, Australia, Brazil, EU, New Zealand, and the United States.
} 
announced on January 14, 2019 its withdrawal from the ICRW pursuant to Article XI of the Convention. ${ }^{35}$

The fact that the IWC is open to accession by non-whaling countries, including land-locked States such as Switzerland, is an asset for improving whale conservation. Indeed, the decisions adopted within the IWC are now also an expression of the will of anti-whaling States representing the worldwide public opinion. In this field, corruption of new IWC Member States by Japanoften land-locked States or developing countries-is suspected by many. ${ }^{36}$ The latter would manipulate these countries in order to obtain support for its whaling agenda. ${ }^{37}$ Indeed, it is no coincidence that the above-mentioned 2018 Japanese proposal "Way Forward" was backed by several of the least developed countries—and therefore more vulnerable to bribery-within the IWC.

Every effort to reform the IWC is hindered by the strong opposition to any change of the status $q u o$ by both whaling and anti-whaling countries. Indeed, a proposal aimed at partially restoring commercial whaling under a mechanism of quotas and a strict monitoring-which could have hindered Japan's withdrawal from the IWC and would have obtained a considerable reduction of catches-was rejected in 2010 at the IWC meeting in Agadir, Morocco. ${ }^{38}$

Furthermore, small cetaceans, such as certain species of whales, dolphins, and porpoises are not within the sphere of competence of the IWC, ${ }^{39}$ which is limited to thirteen species of great whales, such as the bowhead whale, the North Atlantic right whale, and the blue whale. ${ }^{40}$ As the Article analyzes in the following Section, treaties of regional scope have partially filled this gap within the IWC.

\section{CITES}

The two pillars of the international regime on the protection of wildlife are represented by CITES $^{41}$ and the Convention on the Conservation of Migratory Species of Wild Animals

\footnotetext{
${ }^{35}$ Statement on Government of Japan Withdrawal from the IWC, INT'L WHALING COMM'N (Jan. 14, 2019), https://iwc.int/ statement-on-government-of-japan-withdrawal-from-t. According to Article XI of the Convention:

Any Contracting Government may withdraw from this Convention on $30^{\text {th }}$ June, of any year by giving notice on or before $1^{\text {st }}$ January, of the same year to the depository Government, which upon receipt of such a notice shall at once communicate it to the other Contracting Governments. Any other Contracting Government may, in like manner, within one month of the receipt of a copy of such a notice from the depository Government give notice of withdrawal, so that the Convention shall cease to be in force on $30^{\text {th }}$ June, of the same year with respect to the Government giving such notice of withdrawal.

International Convention for the Regulation of Whaling, supra note 19, at art. 11; see also Lisbeth Zimmermann, Is the Commercial Whaling Ban in Danger? Japan's Withdrawal from the International Whaling Commission, PRIF BLOG (Jan. 21, 2019), https://blog.prif.org/2019/01/21/is-the-commercial-whaling-ban-in-danger-japans-withdrawal-from-the-international-whali ng-commission/ (discussing possible scenarios arising from Japan's decision).

${ }^{36}$ See Minister: Whaling Commission Corrupt, THE AGE (June 22, 2006), https://www.theage.com.au/national/ministerwhaling-commission-corrupt-20060622-ge2kk6.html (stating that Ian Campbell, Australian Minister for the Environment and Heritage from 2004 until 2007, made accusations of corruption against Japan in 2006); see also Atsushi Ishi \& Ayako Okubo, An Alternative Explanation of Japan's Whaling Diplomacy in the Post-Moratorium Era, 10 J. INT'L WILDLIFE L. \& POL'y 55 (2007) (discussing Japan's whaling diplomacy and the reasons behind its rejection of anti-whale norms).

${ }^{37}$ See Third Millennium Foundation, Japan's "Vote Consolidation Operation" in the International Whaling Commission, 2007.

${ }^{38}$ Cristian Maquieira, Japan's Withdrawal from the International Whaling Commission: A Disaster that Could Have Been Avoided, ETHICS \& INT'L AFF. (Jan. 2019), https://www.ethicsandinternationalaffairs.org/2019/japans-withdrawal-from-theinternational-whaling-commission-a-disaster-that-could-have-been-avoided/ (last visited May 10, 2019).

${ }^{39}$ Alexander Gillespie, Small Cetaceans, International Law and the International Whaling Commission, 2 MeLB. J. INT'L L. 257 (2001).

${ }^{40}$ Details and Characteristics of the 13 Great Whales, Including the Life Histories of Baleen and Sperm Whales, INT'L Whaling Comm'N (2019), https://iwc.int/lives (last visited May 10, 2019).

${ }^{41}$ Thomas G. Kelch, Globalization and Animal Law: Comparative LaW, International LaW and InTERnational TRADE 222 (2011).
} 
(CMS), adopted in Bonn in 1979. ${ }^{42}$ Those treaties-along with the Ramsar Convention on Wetlands-form the first generation of environmental treaties with universal scope. They are an expression of the sectorial approach that characterized international environmental law in the first phase of its development: Environmental functionalism. ${ }^{43}$

Both treaties request different levels of duties upon Member States depending on where a particular species is listed in specific appendices. CITES includes three appendices. Appendix I lists the most threatened species and requires strict limitations to trading. Appendix II contains species that are not currently endangered, but that could become endangered if their trade is not properly managed. Appendix III concerns those species that Member States-which request unilateral cooperation-declare unilaterally to be in danger. ${ }^{44}$

Appendix I of CITES provides protectives measures to mitigate the potential negative impacts of illegal trade on several species of cetacean, including dolphins, porpoises, and whales ${ }^{45}$ Indeed, exporters must fulfill restrictive conditions in order to export species listed in Appendix I. First, competent national authorities must provide a grant that verifies that the export will not be detrimental to the conservation of the species in question, that the live specimens were not obtained in violation of domestic laws, and that the risk of injury, damage to health, or cruel treatment during shipment has been guaranteed. ${ }^{46}$ Second, an exporter must present an export permit to the customs department of the recipient country. Finally, importation of species listed in Appendix I is also conditional upon a finding that the import will not be detrimental to the survival of the species, that minimum standards of house and care are satisfied, and that the specimen is not to be used for "primarily commercial purposes."

Of particular relevance to cetaceans is paragraph five of Article III, which details the introduction of marine species from the sea. This norm addresses the capture of cetaceans in areas that technically fall outside of the property of a State, meaning beyond the 200 miles of the Exclusive Economic Zone. In such cases, the ICW requests the release of a certificate from a Management Authority of the State of introduction, which must validate that the introduction will not be detrimental to the survival of the species involved, that minimum standards of house and care will be satisfied, and that the specimen is not used for primarily commercial purposes.

To introduce sea species listed in Appendix II, CITES does not require that the specimen in question not be used for primarily commercial purposes, while nevertheless maintaining that welfare standards must be respected and that the capture of such animals not endanger their conservation. ${ }^{47}$ Illegal trade in live specimens of cetaceans, particularly that of smaller species like

\footnotetext{
${ }^{42}$ Annamalai Murugan, International Regime of Environmental Law 77 (2016).

${ }^{43}$ Sergio Marchisio, Diritto Internazionale Dell'ambiente, in DiritTo ambientale: Profili InTERnazionali EUROPEI E COMParati 1 (G. Giappichelli ed., 2017). The 1992 Convention on Biological Diversity (CBD) is instead part of the "environmental globalism," a phase which started with the Rio Conference on Environment and Development. See Convention on Biological Diversity, July 1, 1992, 31 I.L.M. 818 [hereinafter CBD]. The CBD obliges Member States to protect the biological diversity within their jurisdiction and within activities carried out under their control in areas such as the high seas and Antarctica. In particular, Article 8 of the CBD provides that Member States must ensure the conservation and sustainable use of biological resources, protection of habitats, and rehabilitation of degraded species. The CBD established framework principles, such as the "sustainable use" of marine resources that have been then implemented by RMFOs.

${ }^{44}$ The criteria for including species into Appendix I of CITES ('species threatened with extinction') were established during the Conference of States Parties held in Berne in 1976 - The Berne criteria ("[T]o qualify for Appendix I, a species must be currently threatened with extinction.”). Proposals for including a species in Appendix I or II of CITES requires a request for amendment that must be approved by a two-thirds majority of the voting Parties. See Convention on International Trade in Endangered Species of Wild Fauna and Flora art. 15, Mar. 1, 1973, 27 U.S.T. 1087 [hereinafter CITES].

${ }^{45}$ See, e.g., Balaena mysticetus, Eubalaena spp (Balenidae), Balaenoptera acutorostrata (Except the population of West Greenland, which is included in Appendix II), Balaenoptera bonaerensis, Balaenoptera borealis, Balaenoptera edeni, Balaenoptera musculus, Balaenoptera omurai, Balaenoptera physalus, Megaptera novaeangliae (Balaenopteridae), Orcaella brevirostris, Orcaella heinsohni, Sotalia spp. Sousa spp. (Delphinidae). CITES appendix I. Although they still face several threats like illegal trading, especially at the US- Mexico borders, Appendix I has listed sea turtles (Cheloniidae spp) since 1981.

${ }^{46}$ CITES art. 3, para. 2 .

${ }^{47}$ CITES art. 4, para. 6 .
} 
the bottlenose dolphin, has welfare aspects that must not be underestimated, because the welfare of individual cetaceans kept in captivity affects overall conservation. Indeed, keeping caught individual cetaceans in healthy and reproductively active conditions diminishes the demand for replacements from the wild. ${ }^{48}$

CITES is, to date, the only environmental treaty that addresses animal welfare, although only in an incidental manner-specifically, as wild animals are caught or extracted from the wild. Indeed, as animals are brought under human control, a minimum standard of welfare-which is not to be treated "in a cruel manner" ${ }^{4}$ - must be guaranteed by domestic authorities from the moment the animals are confined in cages until the ultimate delivery to the recipient country. For instance, Article VIII of CITES states, "[t]he Parties shall ensure further that all living specimens, during any period of transit, holding or shipment, are properly cared for so as to minimize the risk of injury, damage to health or cruel treatment." ${ }^{50}$ Unfortunately, Article III, which deals with introduction from the sea of any specimen of a species included in Appendix I, fails to address welfare issues that are instead relevant to the condition of captivity of marine mammals. ${ }^{51}$ Indeed, captive management for cetaceans like killer whales or common dolphins can be very difficult due to their high level of cognition and peculiar social needs. As observed by Harrop, the level of welfare that should be guaranteed to animals extracted from the wild is the same as the one that is generally applied to farm animals under the domestic law of the hosting country. ${ }^{52}$

CITES has dealt with the issue of marine mammal conservation in several resolutions, and has established close links with the IWC, which has observer status within CITES. In particular, in Resolution Conference $11.4,{ }^{53}$ CITES recognized the key role of the IWC in the management of whales and as the main source of statistical data on whale stocks. But, it has highlighted that the international and illegal trade of meat and other products of protected species of whales cannot be effectively controlled by the IWC alone. To this aim, CITES recommended to its Parties "not to issue any import or export permit, or certificate for introduction from the sea, under this Convention for primarily commercial purposes for any specimen of a species or stock protected from commercial whaling by the International Convention for the Regulation of Whaling" (Para. 3).

CMS also holds a leading global and regional role in marine mammal conservation. Several cetaceans are included in Appendix I-Migratory species in danger-and Appendix IIMigratory species with an unfavorable conservation status requiring international cooperation for conservation and management. ${ }^{54}$ This treaty is not, however, traditionally considered as having the same normative value of CITES. Indeed, when compared to CMS, CITES has an asset that makes it particularly suitable for protecting marine mammals from overexploitation. Article VIII obliges its Parties to prohibit trade in specimens in violation of the Convention, to penalize such trade, and to allow for the confiscation of specimens illegally traded or possessed-meaning, punishing and preventing the illegal trade of listed cetacean species. Therefore, the State who lands

\footnotetext{
${ }^{48}$ Sue J. Fisher \& Randall R. Reeves, The Global Trade in Live Cetaceans: Implications for Conservation, 8 J. INT'L WILDLIFE L. \& POL'y 315 (2005).

${ }^{49}$ The formula adopted with regard to the phases that move from preparation to shipping, shipping to delivery is that "any living specimen will be so prepared and shipped as to minimize the risk of injury, damage to health or cruel treatment". See CITES art. 3, paras. 2, 4; id. art. 4, paras. 2, 5, 6; id. art. 5, para. 2.

${ }^{50}$ CITES art. 8, para. 3 .

${ }^{51}$ CITES art. 3 , para. 5 .

${ }^{52}$ Stuart Harrop, Climate Change, Conservation and the Place for Wild Animal Welfare in International Law, 23 J. ENVT'L. L. 441 (2011).

${ }^{53}$ Resolution on Conservation of Cetaceans, Trade in Cetacean Specimens and the Relationship with the International Whaling Commission, CITES (Apr. 20, 2000), https://www.cites.org/eng/res/11/11-04.php.

${ }^{54}$ In detail, sixteen cetacean species, such as Basalaena mysticetus, Eubalaena glacialis (North Atlantic), Eubalaena japonica (North Pacific), and Eubalaena australis, are listed in Appendix I, and forty-five cetacean species, including Balaenoptera bonaerensis, Balaenoptera edeni, Balaenoptera borealis, Balaenoptera omurai, and Balaenoptera physalus in CITES appendix II.
} 
and sells parts of those cetaceans listed in Appendices I and II of CITES in clear violation of the Convention is liable under domestic laws that implement CITES-for example, in the United States under the Shark Conservation Act or the Marine Mammals Protection Act. Japan has violated this rule in several occasions, selling the meat of dolphins or whales by disguising it as the meat of other fish species. Indeed, recent techniques to identify the source of the species have been developed and consequently used to uncover the illegal trade perpetrated by Japan. ${ }^{55}$

Furthermore, the CITES Standing Committee (SC) highlighted Japan's violation of trade restrictions for the sei whale, which is listed in Appendix I of CITES, and therefore subject to the severe constraints under Article III, Paragraph 5. Indeed, the SC questioned the numbers of the sei whale specimen caught for "research purposes" in Japan, drawing attention to "the

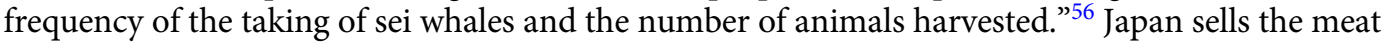
and the blubber of sei whales in order to finance its scientific programs on other whales. In particular, the SC stated that "the frequency and number of introductions from the sea cast doubt on whether the trade is authorized by the Management Authority of Japan 'only in exceptional circumstances,' as recommended in Resolution Conf. 5.10." ${ }^{\prime 2}$ The SC then recommended that "Japan take[] immediate remedial action to comply," threatening the adoption of further actions, including trade sanctions, against Japan. ${ }^{58}$

The main reason behind the SC's conclusion lay in the excessive introduction of sei whales into Japan's territory-some 90 to 100 sei whales annually during the period of 2007-2016 — which could not constitute, therefore, "exceptional circumstances," ${ }^{59}$ but would rather imply a commercial purpose. In fact, it underlined that "the sale of meat and blubber on the domestic market is an activity that can generally be described as 'commercial' because its purpose is to obtain economic benefit. .. ." 60

Comparatively, the Solomon Islands have a different type of problem. Despite joining CITES in 2007, the Solomon Islands faces the problem of dolphin trafficking. In fact, as reported by the non-governmental organization Dolphin Project, the phenomena of dolphin trafficking is widely diffused and strictly related to the high level of corruption of local authorities that, in exchange for money, allow the illegal capture and exportation of wild bottlenose dolphins to be sold to aquariums. ${ }^{61}$

On the other side, the main limit of CITES is that it is a wildlife treaty whose rules only apply when the marine species listed in Appendices I or II are illegally caught for commercial purposes. Consequently, there are no penalties if the turtles, dolphins, or whales listed in CITES Annexes are caught for human consumption, despite the trade of their meat being prohibited. ${ }^{62}$ Indeed, CITES does not limit domestic use of marine species. The decision to allow or forbid the fishing activity of a determined species within the limits of the territorial sea or the EEZ is a political choice by national authorities. For this reason, despite its ethically questionable brutality, the seasonal slaughter of dolphins off the coast of Taiji is lawful.

Another shortcoming of CITES lies in its nature. As highlighted by Wigginton, "it is responsive and not preventative." ${ }^{33}$ In other words, CITES is not a treaty whose goal is to prevent the

\footnotetext{
${ }^{55}$ Annalisa Berta, James Sumich \& Kit Kovacs, Marine Mammals: Evolutionary Biology 463 (2d ed. 2005).

${ }^{56}$ CITES Secretariat, Seventieth Meeting of the Standing Committee Document, CITES para. 57 (Oct. 2018), https://cites.org/ sites/default/files/eng/com/sc/70/E-SC70-27-03-04.pdf; CITES art. 3.

${ }^{57}$ CITES Secretariat, supra note 56 , at para. 57.

${ }^{58}$ CITES Secretariat, supra note 56, at para. $27(3)(4)$ (Introduction from the sea of sei whale (Balaenoptera borealis) by Japan).

${ }^{59} \mathrm{Id}$.

${ }^{60}$ CITES Secretariat, supra note 56, at para. 59; see also Erica Jayne Lyman \& Olivier Jamin, Japan's Introduction from the Sea of Sei Whale Meat: The Breaking Point of CITES?, 1 INT'L J.L. \& PUB. ADMIN. 68 (2018).

${ }^{61}$ Dolphin Tracking, DOLPHIN PROJECT (2019), https://dolphinproject.com/campaigns/solomon-islands-campaign/ dolphin-trafficking/ (last visited May 7, 2019).

${ }^{62}$ GugGisberG, supra note 11 , at 216.

${ }^{63}$ Jared R. Wigginton, Governing a Global Commons: Sharks in the High Seas, 25 VILL. ENVT'L. L.J. 431, 448 (2014).
} 
harvesting of a particular species, but instead it aims at protecting a determined species only when it is at risk of extinction and has therefore passed a determined threshold. In fact, in order to be listed in Appendices I or II, a species must reach an extinction threshold, which inherently implies that the protection is guaranteed to be ex post and not ex ante.

\section{Treaties of Regional Scope}

Treaties and conservation programs of regional scope have been largely adopted in response to the perceived gaps of the IWC legal regime, namely the low number of cetaceans that are protected by the ICRW. ${ }^{64}$ Currently, the IRCW only affords a high degree of protection to great whales.

The North Atlantic Marine Mammals Commission (NAMMCO), a regional pro-hunting organization composed of pro-whaling countries, like Faroe Islands, Greenland, Iceland, and Norway, responds to the discontent of Nordic countries towards the IWC moratorium. ${ }^{65}$ Indeed, this organization does not intend to challenge small cetaceans hunting, but rather to manage their exploitation in a manner that is coherent with optimum utilization of marine resources and respect for the welfare of animals. In fact, NAMMCO establishes annual quotas not only for great whales, but also for small cetaceans, making note of the methods of hunting that take account the welfare of the animals that are caught. Therefore, unlike the vast majority of EU countries, Nordic countries continue to consider marine mammals not as marine species endowed with sophisticated intellectual and emotional abilities, but rather as a commodity that has a market value and can therefore be exploited.

The NAMMCO goals of sustainable harvesting are not, in theory, in conflict with those of the IWC, because the latter also has in its original mandate the regulation and not the prohibition of whaling. ${ }^{66}$ Put differently, other regional standards applicable to marine mammals are based on a conservation philosophy that enhances the conservation of marine mammals by taking into account their peculiarities - particularly, those of cetaceans. These treaties of regional scope also provide protection to small cetaceans while dealing with modern threats to their survival, such as habitat depletion and marine pollution.

The first regional rules have been developed within the Mediterranean Action Plan (MAP), promoted by UNEP in 1975, and its Convention on the Protection of the Mediterranean Sea against Pollution-for example, the Barcelona Convention. ${ }^{67}$ In particular, the Protocol Concerning Specially Protected Areas and Biological Diversity in the Mediterranean (SPA Protocol) is worth mentioning. ${ }^{68}$ The SPA Protocol applies to "the area of the Mediterranean Sea," including the seabed and its subsoil, internal waters, and wetlands. ${ }^{69}$ The Parties to the SPA Protocol further commit themselves to "protect, preserve and manage in a sustainable and environmentally sound way areas of particular natural or cultural value" 70 through the

\footnotetext{
${ }^{64}$ A specific Conservation Management Plan expressly devoted to a small cetacean - the first ever adopted for a small cetacean species within the IWC-was approved in 2016. It targets the Franciscana Dolphin, also known as La Plata River Dolphin. Franciscana Dolphin, INT'L WHALING COMM'N (2019), https://iwc.int/franciscana-dolphin (last visited May 7, 2019).

${ }^{65}$ NAMMCO provides advice to the national governments on the conservation status and responsible hunting methods of marine mammals. Unlike the IWC, it has competence over small cetaceans, such as narwhal and beluga whales. See Grete Hovelsrud-Broda, NAMMCO - Regional Cooperation, Sustainable Use, Sustainable Communities, in THE FuTURE OF Cetaceans in a Changing World 144, 144 (William C.G. Burns \& Alexander Gillespie eds., 2003).

${ }^{66}$ Nevertheless, the IWC moratorium also applies to the North Atlantic.

${ }^{67}$ The Barcelona Convention was adopted in 1976 and entered into force on July 22, 1978. It was amended in 1995 and changed its name to the Convention for the Protection of the Marine Environment and the Coastal Region of the Mediterranean.

${ }^{68}$ Protocol Concerning Specially Protected Areas and Biological Diversity in the Mediterranean, Dec. 14, 1999, 1999 O.J. (L 322) 3 (EC) [hereinafter SPA Protocol].

${ }^{69} I d$. art. 2.

${ }^{70} I d$. art. 3.
} 
establishment of Specially Protected Areas ${ }^{71}$ or a list of Specially Protected Areas of Mediterranean Importance (SPAMI). ${ }^{72}$ The list may include sites which "are of importance for conserving the components of biological diversity in the Mediterranean" and/or "contain ecosystems specific to the Mediterranean area or the habitats of endangered species. .. ." ${ }^{\text {"73 }}$ In particular, Annex II of the SPA Protocol envisages a List of Endangered or Threatened Species. ${ }^{74}$

Nineteen species of Mammalia-such as Balaenoptera acutorostrata, Balaenoptera borealis, Balaenoptera physalus, Delphinus delphis, Eubalaena glacialis, and Globicephala melas, Grampus griseus - are listed in Annex II. To date, 35 sites ranging from the coasts of Spain and Morocco to those of Cyprus and Lebanon ${ }^{75}$ have been established. Of these, however, only one, the Pelagos Sanctuary, extends beyond the twelve-mile border of the territorial sea. Within the Council of Europe, the Bern Convention ${ }^{76}$ is another conservation treaty that obliges State Parties to take appropriate legislative measures in order to protect strictly protected flora species under Appendix I, strictly protected fauna species under Appendix II, and protected fauna species under Appendix III. Thirty species of cetaceans, including Balaenopteridae: Balænoptera acutorostrata (Med.), Balænoptera borealis (Med.), Balaenoptera edeni, Balaenoptera physalus, Megaptera novaeangliae (longimana, nodosa), and Sibbaldus Balaenoptera musculus, are listed in Appendix II. ${ }^{77}$

The Agreement on Cooperation in Research, Conservation and Management of Marine Mammals in the North Atlantic (North Atlantic Agreement), the Agreement on the Conservation of Small Cetaceans of Baltic and North Baltic, North East Atlantic, Irish and North Seas (ASCOBANS), ${ }^{78}$ and the Agreement on the Conservation of Cetaceans of the Black Sea, Mediterranean Sea and Contiguous Atlantic Area (ACCOBAMS) are relevant regional arrangements for marine mammal conservation. They fill the regulatory gaps of the current legal regime by taking into account small cetaceans or dolphins that are not within the ICW sphere of competence. Furthermore, they deal with the modern threats to cetaceans, such as climate change, plastic pollution, and underwater noise.

Particularly related to marine mammals conservation is the 1996 ACCOBAMS, which was negotiated and drafted within the CMS due to the migratory nature of these species and which applies to coastal Mediterranean and Black Sea countries. ${ }^{79}$ Annex I lists the cetaceans of the Mediterranean, Black Sea, and Atlantic Contiguous Area. It is a treaty with a regional scope applying to all the maritime waters of the Black Sea, the Mediterranean, and, notably, the contiguous

\footnotetext{
${ }^{71} I d$. art. 4.

${ }^{72} I d$. art. 8.

${ }^{73} \mathrm{Id}$.

${ }^{74}$ U.N. Environment Programme, Protocol Concerning Specially Protected Areas and Biological Diveristy in The Mediterannean AnNex II: List of Endangered or Threatened Species (2013), http://www.rac-spa.org/sites/default/ files/annex/annex_2_en_2013.pdf.

${ }^{75}$ SPAMIs, Regional Activity Center for Specially Protected Areas (2019), http://www.rac-spa.org/spami (last visited May 7, 2019).

${ }^{76}$ Convention on the Conservation of European Wildlife and Natural Habitats, Sept. 19, 1979, [1979] CETS 104 [hereinafter Bern Convention].

${ }^{77} I d$.

${ }^{78}$ The conclusion of this Agreement was fostered by growing concern from the scientific community about fishery bycatch of harbor porpoises and dolphins in the North Sea. State Parties are obliged to adopt "conservation, research and management measures" tailored to small cetaceans. These measures, in particular, should be addressed towards "[reducing] harmful pollutants (including noise), attempting to introduce modifications of fishing gear that would reduce cetacean bycatch, working to reduce the depletion of cetacean food resources, and reducing disturbance of small cetaceans, in particular working to minimize the impacts of underwater noise.” Edward C.M. Parsons, An Introduction to Marine Mammal Biology AND CONSERVATION 276 (2012).

${ }^{79}$ Memorandum of Understanding Concerning the Conservation of the Manatee and Small Cetaceans of Western Africa and Macaronesia, CMS (2008), http://www.iucn-csg.org/wp-content/uploads/2010/03/TRE146853.pdf (participating countries including: Angola, Benin, Cape Verde, Chad, Congo, Côte d'Ivoire, Equatorial Guinea, Gabon, Ghana, Guinea, GuineaBissau, Liberia, Mali, Mauritania, Niger, Portugal, and Togo).
} 
Atlantic area west of the Straits of Gibraltar, the "Area of extension." The area covered by ACCOBAMS encompasses the Pelagos Sanctuary devoted to Marine Mammals. Therefore, this Agreement covers all maritime zones within its field of application, irrespective of their classification within the United Nations Convention on the Law of the Sea (UNCLOS), and regardless of whether they are internal waters, wetlands, territorial sea, EEZ, or ecological protection areas. It is a legal conservation tool that obliges its Parties "to achieve and maintain a favorable conservation status for cetaceans." ${ }^{80}$ Further, the specific Parties must cooperate in order to establish protected areas and adopt all the necessary legislative measures in order to avoid "deliberate taking of cetaceans." 81

Article I of the Agreement applies to all the cetaceans that have a range, which means "all areas of water that a cetacean inhabits, stays in temporarily, or crosses at any time on its normal migration route within the Agreement area." 82 Annex I to the Agreement contains an example list of cetaceans of the Black Sea-for example, Phocoena phocoena, Tursiops truncates, and Common dolphin - and an example list of cetaceans of the Mediterranean Sea and the Contiguous Atlantic Area-for example, Pseudorca crassidens, Orcinus orca, Globicephala melas, Balaenoptera acutorostrata, Balaenoptera borealis, and Balaenoptera physalus. Therefore, unlike ASCOBANS, it applies to all cetaceans, not just small cetaceans, in the Area covered.

\section{Regional Rules: The Case of the European Union}

European fisheries operate in EU waters in the North Sea and the North East Atlantic and the Norwegian and Faroes waters, as well as in all the world oceans, including the Atlantic, Indian, and Pacific Oceans. EU fisheries do not traditionally target marine mammals, which are mainly protected within EU wildlife law and treaties of regional scope. Nevertheless, growing public attention towards animal welfare, which is the pillar of EU animal policies, has entailed a general ban on cetacean and seal hunts within EU waters, with the exception of the slaughter of the pilot whale in the Faroe Islands.

\section{EU Environmental Policy and Marine Mammals}

To date, twenty-three cetaceans are included in the European Red List of Threatened Species. ${ }^{83}$ These account for $21.7 \%$ of threatened species amongst mammals. Marine mammal management falls both within the Common Fisheries Policy (CFP) and the shared competence on the environment. ${ }^{84}$ Indeed, the integration principle first envisaged by the Amsterdam Treaty recognizes the importance of integrating environmental protection requirements into Community policies and activities, including within the CFP. ${ }^{85}$ The relevant legislation is provided by the Birds

\footnotetext{
${ }^{80}$ Agreement on the Conservation of Cetaceans of the Black Sea, Mediterranean Sea and Contiguous Atlantic Area, art. 2, para. 1, Nov. 24, 1996, 36 I.L.M. 777 [hereinafter ACCOBAMS].

${ }^{81}$ "Taking" is defined as "taking, hunting, fishing capturing, harassing, deliberate killing, or attempting to engage in any such conduct". Convention on the Conservation of Migratory Species of Wild Animals, art. 1, para. 1, June 23, 1979,1651 U.N.T.S. 28395 [hereinafter CMS]; Agreement on the Conservation of Seals in the Wadden Sea, Oct. 16, 1990, 2719 U.N.T.S. 48123 (regarding seals, exceptions under paragraph two of article II are only allowed in the event of emergency situations or when scientific research that must be carried with specific authorization and that cannot be lethal and must be conducted in the natural environment of the cetacean (in situ)).

${ }^{82}$ ACCOBAMS art. 2, para. 3.

${ }^{83}$ Eur. Comm'n on Env't, European Red List, Eur. CoMm'N (Nov. 28, 2018), http://ec.europa.eu/environment/nature/ conservation/species/redlist/index_en.htm.

${ }^{84}$ Consolidated Version of the Treaty on the Functioning of the European Union, Dec. 10, 2012, 2012 O.J. (C 326) 47 [hereinafter TFEU] (containing a list of products including fish, crustaceans, and mollusks but not marine mammalsthe only reference to marine mammals is in Chapter 15.04 "Fats and oil, of fish and marine mammals, whether or not refined").

${ }^{85} I d$. art. 11 ("[E]nvironmental protection requirements must be integrated into the definition and implementation of the Union policies ... in particular with a view to promoting sustainable development.”).
} 
Directive $^{86}$ and by the Habitats Directive, ${ }^{87}$ whose legal foundation is provided by Article 192 of the Treaty on the Functioning European Union (TFEU) that established the Natura 2000 ecological network..$^{88}$

With regard to wild animals and the protection of biodiversity, which necessarily extends to marine mammals, in 2010, the EU adopted an ambitious biodiversity strategy to be carried out between 2011 and 2020. ${ }^{89}$ The strategy was based on seven targets: (1) Protect species and habitats; (2) maintain and restore ecosystems; (3) achieve more sustainable agriculture and forestry; (4) make fishing more sustainable and seas healthier; (5) combat invasive alien species; (6) help stop the loss of global biodiversity; and (7) horizontal measures for its implementation, including financing, partnership, and knowledge base.

The Marine Strategy Directive ${ }^{90}$ obliges EU Member States to take the measures necessary to reduce the impact of human activities on the marine environment to achieve or maintain a good environmental status of the marine environment by 2020. In particular, the "qualitative descriptors for determining good environmental status" listed in Annex I of the Directive included, inter alia, two of the major threats to marine mammals' welfare in the EU seas: Marine litter and underwater noise. ${ }^{91}$ Particularly relevant for cetaceans is Council Regulation (EEC) No. 348/81 of January 20, 1981 on common rules for imports of whales or other cetacean products. This Regulation provides a ban on the import of all whale products. ${ }^{92}$ Therefore, Norway and Iceland cannot export whale products to the EU market. ${ }^{93}$

In contrast to Regulation No. 348/81 — which regulates the trade of all whale products in order to control their exploitation-the Habitat Directive obliges EU Member States to establish special conservation areas (ZSC) for species listed in Annex II and a mechanism of strict protection for those species listed under Annex IV(a)_-"Species of community interest in need of special protection." Annex II mentions amongst the cetacea under protection two species-Phocoena phocoena and Tursiops truncates - while Annex IV(a) makes reference to "all species" of cetaceans. The measures that must be set up by Member States through the establishment of protected areas must prohibit, in particular: "[A]ll forms of deliberate capture or killing; deliberate disturbance, particularly during periods of breeding, rearing, hibernation and migration; deterioration or destruction of breeding sites or resting places." ${ }^{4}$ In addition, as observed by Bowman and others, ${ }^{95}$ the export of whale meat to the EU common market is prohibited under paragraph two of Article 12, which bans "the keeping, transport and sale or exchange, and offering for sale or exchange, of specimens taken from the wild" that form part of the species listed under Annex

\footnotetext{
${ }^{86}$ Council Directive 79/409/EEC, 1979 O.J. (L 103) 1. This Directive was amended by Council Directive 2009/147/EC of the European Parliament and of the Council of 30 November 2009 on the conservation of wild birds.

${ }^{87}$ Council Directive 92/43/EEC of May 21, 1992, on the Conservation of Natural Habitats and of Wild Fauna and Flora, 1992 O.J. (L 206) 7 [hereinafter Habitats Directive].

${ }^{88}$ Eur. Comm'n on Env't, Natura 2000, EUR. COMM'N (2019), http://ec.europa.eu/environment/nature/natura2000/ index_en.htm (last visited May 7, 2019). The main goal of the Directive is to create a coherent European ecological network known as Natura 2000 - Article 3(1) — which protects habitats and species of "Community interest" through the establishment of Special Areas of Conservation (SACs) or Special Protection Areas (SPAs) under the Birds Directive.

${ }^{89}$ Communication from the Commission to the European Parliament, the Council, the Economic and Social Committee and the Committee of the Regions, Our Life Insurance, Our Natural Capital: An EU Biodiversity Strategy to 2020, COM (2011) 244 final (May 3, 2011).

${ }^{90}$ Directive 2008/56/EC, of the European Parliament and of the Council of June 17, 2008, Establishing a Framework for Community Action in the Field of Marine Environmental Policy (Marine Strategy Framework Directive), 2008 O.J. (L 164) 19.

${ }^{91} I$ d. at annex I ("Properties and quantities of marine litter do not cause harm to the coastal and marine environment [and] [i]ntroduction of energy, including underwater noise, is at levels that do not adversely affect the marine environment.").

${ }^{92}$ See Council Regulation (EEC) 348/81 of Jan. 20, 1982, on Common Rules for Imports of Whales or Other Cetacean Products, 1982 O.J. (L 39) 1 (discussing that all cetaceans are considered as though they were in Appendix I of CITES).

${ }^{93}$ Furthermore, ceasing to be a whaling country can be considered a conditio sine qua no for EU accession.

${ }^{94}$ Habitats Directive art. 12.

${ }^{95}$ Michael Bowman, Peter Davies \& Catherine Redgwell, Lyster’s International Wildlife LaW, 188 (2d ed. 2010).
} 
IV(a). ${ }^{96}$ Member States are, furthermore, obliged to maintain or restore species populations and habitats to a "favourable conservation status." 97

The CITES Regulation, ${ }^{98}$ then, is the legal tool for implementing CITES within the EU Common Market, because it reproduces within the EU the appendices to CITES, including those related to whales and other cetaceans. ${ }^{99}$ Great whales, independent from their conservation status, were listed in Annex I of the regulation, because the EU envisaged stricter domestic measures. Therefore, species of cetaceans listed in CITES Appendix II, or even those not listed, were given a high standard of protection. Accordingly, the import and the sale of any whale meat or other whale product within the EU common market is prohibited without the issuance of a special import permit. ${ }^{100}$ Nevertheless, this import permit cannot be issued if the specimen is to be used primarily for commercial purposes. ${ }^{101}$

There are, however, European political entities that still practice whaling. Greenland and the Faroe Islands, although both parts of the Kingdom of Denmark, enjoy a high level of autonomy from the central government. Greenland practices seasonal aboriginal whaling, taking advantage of the aboriginal exemption of the ICRW, while the Faroe Islands have an ancient tradition of pilot whale slaughter (grindadráp). The problem with the Faroe Islands lies first in the fact that pilot whales are not considered great whales and are therefore not protected by the IWC's moratorium. Thus, the position of the Danish representative within IWC is quite complicated, because it forms the nexus of claims of three different stakeholders: The EU, Denmark, and the Faroe Islands.

\section{EU Welfare Policy on Marine Mammals}

Marine mammals, and in particular dolphins and seals, are traditionally considered in Western culture as being among the cutest of all animals, additionally fitted with high cognitive capabilities when compared to common fish. Major scientific research on the social behaviors and intelligence of dolphins and whales has shown that the two exhibit a higher capacity for suffering than common fish, because they have high amounts of $\mathrm{C}$-fibers that allow them to experience pain. ${ }^{102}$

Comparatively, in other cultures, like South East Asian or Nordic countries, dolphins, seals, and whales are instead commonly slaughtered ${ }^{103}$ and are part of the diet of these populations. During the hunting season in Japan, as reported by the award-winning documentary The Cove, hunters push dolphins into a bay on the shores of Taiji in order to slaughter them. In Western society, the market value of cetaceans is low, because the consumption of dolphin or seal meat, for instance, is not part of the Western culture. ${ }^{104}$ Welfare issues are therefore quite relevant for EU policies concerning marine mammal conservation, as witnessed by the legal regime concerning seals. Indeed, the EU Seals Regime under the seal pups Directive ${ }^{105}$ affords

\footnotetext{
${ }^{96}$ These prohibitions apply within the EEZ of EU Member States; see also R v. Sec'y of State for Trade and Indus. [1999] All ER (D) 1232.

${ }^{97}$ Habitats Directive arts. 2, 12, 16.

${ }^{98}$ Council Regulation 338/97 of Dec. 9, 1996, on the Protection of Species of Wild Fauna and Flora by Regulating Trade Therein, 1997 O.J. (L 61) 1 (EC).

${ }^{99}$ Whales are included in Annex A.

${ }^{100}$ CITES art. 4.

${ }^{101}$ CITES art. 8.

${ }^{102}$ In the past, dolphins were heavily hunted by European fishermen that considered them as competitors, because they also consume a high amount of fish to survive. In the light of the exceptional sensitive cognition of dolphins, some scholars claim that they can be considered as nonhuman persons and are therefore entitled to a moral standing as individuals. See THOMAS I. White, In Defense of Dolphins: The New Moral Frontier (2007).

${ }^{103}$ The hunting season in Japan is from September until March.

${ }^{104}$ Dolphins and seals are thus unlike bluefin tuna, which are being hunted to extinction due to the high request of its meat.

${ }^{105}$ Council Directive 83/129/EEC of Mar. 28, 1983, Concerning the Importation into Member States of Skins of Certain Seal Pups and Products Derived Therefrom, 1983 O.J. (L 91) 30.
} 
special protections to seals by prohibiting the import of seal pup products into the EU. Additionally, Regulation No. 1007/2009 bans trade in seal products throughout the EU internal market ${ }^{106}$ on the ground of ensuring the welfare of animals. ${ }^{107}$

Regulation No. 1007, in particular, recognizes that "seals are sentient beings that can experience pain, distress, fear and other forms of suffering," 108 and that the ban was adopted "in response to concerns of citizens and consumers about the animal welfare aspects of the killing and skinning of seals and the possible presence on the market of products obtained from animals killed and skinned in a way that causes pain, distress, fear and other forms of suffering."109

To further elaborate on the Regulation's restrictions, in addition to the other conditions that the Inuit populations must fulfil in order to be allowed to place seal products on the EU market, the hunt must be conducted "in a manner which has due regard to animal welfare, taking into consideration the way of life of the community and the subsistence purpose of the hunt." 110 Canada and Norway, as seal-hunting States, challenged this Regulation, filing a complaint before the WTO Dispute Settlement Body in 2011. ${ }^{111}$ The WTO Appellate Body rejected the claims of Canada and Norway in its final report on May 22, 2014, and stated that the ban pursues a legitimate objective, while nevertheless recalling, inter alia, the animal welfare principle. ${ }^{12}$ This important ruling confirms the key role played by the animal welfare principle in shaping and orienting the EU policy on animal protection. ${ }^{113}$

Welfare issues were also noted by the European Court of Justice in the landmark case Inuit Tapirit Kanatami et al. II (Seal Products Case). ${ }^{114}$ The Court found that he cruelty of the practice of seal killing and skinning was, indeed, a violation of a legitimate public interest under Article 13 of the TFEU, which relates to the protection of the welfare of animals as sentient beings.

\footnotetext{
${ }^{106}$ Regulation 1007/2009 of the European Parliament and of the Council of Sept. 16, 2009, on Trade in Seal Products, 2009 O.J. (L 286) 36 (EC) [hereinafter Regulation on Trade in Seal Products]; see also Commission Regulation 737/2010 of Aug. 10, 2010, Laying Down Detailed Rules for the Implementation of Regulation 1007/2009 of the European Parliament and of the Council on Trade in Seal Products, 2010 O.J. (L 216) 1 (EU); Regulation 2015/1775 of the European Parliament and of the Council of Oct. 6, 2015 amending Regulation 1007/2009 on Trade in Seal Products and Repealing Commission Regulation 737/2010, 2015 O.J. L (261) 1 (EU) [hereinafter Regulation 2015/1775]. See also Declaration of the European Parliament on Banning Seal Products in the European Union, 2006 O.J. (C 306) 194; Eur. Parl. Ass., Reply of the Comm. of Ministers, 1005 ${ }^{\text {th }}$ Sess., Doc. No. 11386 (2007) (regarding seal hunting and Recommendation 1776).

${ }^{107}$ Donald M. Broom, International Animal Welfare Perspectives, Including Whaling and Inhumane Seal Killing as a Public Morality Issue, in Animal Law and Welfare - International Perspectives 45, 54 (Deborah Cao \& Steven White eds., 2016).

${ }^{108}$ Regulation on Trade in Seal Products, supra note 105, at para. 1.

${ }^{109}$ Id. para. 6.

${ }^{110}$ Regulation 2015/1775, supra note 105, at art. 3.

111 WTO, Dispute settlement: dispute DS400 and dispute DS 401. European Communities—measures prohibiting the importation and marketing of seal products; more information, https://www.wto.org/english/tratop_e/dispu_e/cases_e/ 1pagesum_e/ds401sum_e.pdf (last visited May 10, 2019). Canada and Norway are amongst the few countries of the world community that still allow seal hunting, despite the fact that the import of seal fur is prohibited by all major markets-including the Russian Federation, USA, and India; see Urge Canada to End its Shameful Seal Slaughter, PETA (2019), https://support. peta.org/page/1144/action/1 (last visited May 7, 2019).

${ }^{112}$ Rob Howse, Joanna Langille \& Katie Sykes, Sealing the Deal: The WTO's Appellate Body Report in EC - Seal Products, ASIL INSIGHTS (2014), https://www.asil.org/insights/volume/18/issue/12/sealing-deal-wto\%E2\%80\%99s-appellate-bodyreport-ec-\%E2\%80\%93-seal-products.

${ }^{113}$ Further, to ban the import of seals product, the EU acceded to CITES in 2015.

${ }^{114}$ On September 3, 2015, the European Court of Justice definitively refused the appeal presented by the Canadian nonprofit organization Inuit Tapiriit Kanatami-which represents a group of seal hunters belonging to the Inuit populationagainst the previous judgment of April 25, 2013. ECJ, Case C-583/11, Inuit Tapiriit Kanatami v. Parliament, ECLI:EU: C:2013:625, Judgment of 3 October 2013. For a detailed reconstruction of the Inuit saga, see Simone Vezzani, The Inuit Tapiriit Kanatami II Case and the Protection of Indigenous Peoples' Rights: A Missed Opportunity?, 1 EUR. PAPERS 307 (2016).
} 
In addition, the new Regulation No. $1775 / 2015^{115}$ highlights in its Preamble that seals are slaughtered in a manner inconsistent with the respect of animal welfare. ${ }^{116}$ Therefore, the EU guarantees a high level of protection to marine mammals, even if it is not a party to the Whaling Convention and has only observer status within the IWC-as is the case with the policy of most States in the international community. Single EU Member States can decide whether to support those measures enhancing whale protection but cannot vote in favor of any measure within IWC that lowers the standard of protection of the environment below that afforded under Article 193 of the TFEU. ${ }^{117}$

EU marine mammal policy can therefore be included within the more general EU policy of special care for animal welfare. Indeed, Article 13 of the TFEU specifically recognizes that the EU must give full regard to the welfare requirements of animals "in formulating and implementing the Union's agriculture, fisheries, transport, internal market, research and technological development and space policies." Animal welfare is a European concern, because the EU recognized that animals are sentient beings, capable of experiencing suffering and psychological and physical pain. This has led to a more ethically sound legislative coverage regarding the use of animals, including, for example, in sensitive areas - for example, cloning of farm animals for food or experimentation. ${ }^{118}$ Therefore, as a consequence of the cruelty inherent to the practice of hunting and skinning, in addition with the traditional concerns related to fisheries management to avoid over exploitation of fish stocks, the EU has increasingly taken into account the ethical issues regarding the reduction of suffering in those animals when dealing with marine mammals. Despite these legal advancements, however, there is still a clear divide between EU and its Member States and some Nordic countries ${ }^{119}$ with regard to the permissibility of whaling and hunting of small cetaceans and seals.

\section{Indirect Protection}

Fisheries law provides indirect protection to marine mammals when it sets rules in order to avoid unsustainable fishing and the bycatch of non-target species.

\section{Fisheries Law}

Overfishing, Illegal fishing, unreported and unregulated (IUU) fishing, and bycatch are literally emptying our oceans, because more fish are caught than their reproductive capacity can sustain. Concern is growing over the condition of the world's oceans and the main causes of non-sustainable fisheries. The reason behind the rapid decline of fish populations is related to factors such as

\footnotetext{
${ }^{115}$ Regulation 2015/1775, supra note 105 , at preamble.

${ }^{116}$ Paragraph 1 of Regulation 2015/1775 reads:

Regulation (EC) No 1007/2009 of the European Parliament and of the Council was adopted with the objective of eliminating obstacles to the functioning of the internal market due to differences in national measures regulating trade in seal products. Those measures were adopted in response to public moral concerns about the animal welfare aspects of the killing of seals and the possible presence on the Union market of products obtained from seals killed in a way that causes excessive pain, distress, fear and other forms of suffering. Such concerns were supported by evidence showing that a genuinely humane killing method cannot be consistently and effectively applied and enforced in the specific conditions in which seal hunting takes place.

${ }^{117}$ Geert De Baere, EU External Action, in European UnION LAW, 710, 752. (Catherine Barnard \& Steve Peers eds., 2017).

${ }^{118}$ David Fraser, Understanding Animal Welfare: The Science in its Cultural Context (2008) (discussing the concept of animal welfare and its legal evolution); Anne Peters, Liberté, Égalité, Animalité: Human-Animal Comparisons in Law, 5 Transnat'L. Envtl. L. 25 (2016) (discussing animal welfare in the Lisbon Treaty); Diane Ryland \& Angus Nurse, Mainstreaming After Lisbon: Advancing Animal Welfare in the EU Internal Market, 3 EUR. ENERGY \& ENVTL. L. REV. 101 (2013).

${ }^{119}$ The pro-whaling Nordic countries are Norway, Iceland, and Denmark (including Faroe Islands and Greenland). Finland and Sweden, instead, do not engage in whaling.
} 
the application of modern technologies to fishing and the excessive subsidies provided to the fish industry. ${ }^{120}$ With regard to the United Nations Convention on the Law of the Sea (UNCLOS), scholars have highlighted the failure of the scientific theory of the maximum sustainable yield (MSY) of the single-species approach, at the bottom of UNCLOS policy on fishing management, that has paved the way to overexploitation instead of sustainable fishing. ${ }^{121}$ In particular, the tragedy of the commons, as first theorized by Garrett Hardin in 1968, is now unfolding into the "tragedy of the seas" resulting from the open access regime of the high sea. ${ }^{122}$ As a result of the decline of fish stocks, the large scale or industrial high sea fishing industry is facing a deep crisis that requires deeply reforming fisheries law.

\section{The Concept of Sustainable Fisheries as the Basic Principle of Future Efforts}

Fisheries management has been amongst the first examples of efforts towards the preservation of marine resources for commercial purposes. In 1881, the North Sea Conference was convened in order to reduce the harvesting of Cod, Haddock, and Plaice Stocks, with the first conservationbased treaty being the North Pacific Fur Seal Convention of 1911. The Parties-Japan, Russia, United Kingdom, and USA - committed themselves to halt open-water seal hunting. It was the first international agreement to address wildlife conservation issues.

The legal regime associated with fisheries management has evolved over time with the adoption of UNCLOS and the UN Fish Straddling Agreement and an increased institutionalized cooperation on exploitation and conservation of high sea marine resources, particularly through the contribution of Regional Fisheries Management Organizations (RFMOs). ${ }^{123}$ The most important development in the field of fisheries law was, however, related to the translation of the concept of sustainable development to the sector of fisheries — sustainable fisheries — affirmed at the 1992 United Nations Conference on Environment and Development (UNCED) in Rio. The concept of sustainable fisheries was first promoted under the auspices of Food and Agricultural Organization (FAO) through the adoption of the 1995 Code of Conduct for Responsible Fisheries ${ }^{124}$ and the Agreement to promote compliance with international conservation and management measures by fishing vessels on the high seas. Following the necessity to improve the Code of Conduct, in 2001 FAO promoted the Reykjavik Declaration on Responsible Fisheries in the Marine Ecosystem, which affirms the "clear need to introduce immediately effective management plans with incentives that encourage responsible fisheries and sustainable use of marine ecosystems, including mechanisms for reducing excessive fishing efforts to sustainable levels. .. ."125

\footnotetext{
${ }^{120}$ Yoshifumi Tanaka, The Changing Approaches to Conservation of Marine Living Resources in International Law, 71 HeIDELBERG J. INT'L. L. 291 (2011).

${ }^{121}$ André E. Punt \& Anthony D.M. Smith, The Gospel of Maximum Sustainable Yield in Fisheries Management: Birth, Crucifixion and Reincarnation, in Conservation of Exploited SPECIES 41 (John D. Reynolds et al. eds., 2001) (discussing the controversial debate within fisheries science on the MSY's concept); Douglas P. Swain, Life-History Evolution and Elevated Natural Mortality in a Population of Atlantic Cod (Gadus morhua), 4 Evolutionary APPLICATIONs 18 (2010) (discussing one milestone example of failure of the MSY's concept is provided by the collapse of the population of Cod, Gadus morhua in the Atlantic Ocean).

${ }^{122}$ Garrett Hardin, The Tragedy of the Commons, 162 SCIENCE 1243 (1968) (theorizing in 1968 that when a resource is under an open access regime, individuals tend to maximize their self-interest by over-exploiting it rather than protecting it).

${ }^{123}$ RFMOs are international organizations created by States with fishing interests in a particular area of the ocean or of a particular species. They have a normative power because they can adopt compulsory conservation and management measures addressed to Member States. The international fisheries regime crafted by RMFOs is aimed at reducing the impact of over fishing and bycatch on the populations of fish stocks, because their depletion can have a negative impact on the fishing industry. See Regional Fisheries Management Organisations (RFMOs), EUR. COMM'N (2019), https://ec.europa.eu/fisheries/cfp/ international/rfmo_en.

${ }^{124}$ Code of Conduct for Responsible Fisheries, FAO (Oct. 31, 1995), http://www.fao.org/3/a-v9878e.htm [hereinafter FAO Code of Conduct].

${ }^{125}$ Reykjavik Declaration on Responsible Fisheries in the Marine Ecosystem App. I (2001), http://www.fao.org/ fishery/docs/DOCUMENT/reykjavik/y2198t00_dec.pdf.
} 
Humankind, accordingly, is realizing that fish stocks are not an unlimited resource. The United Nations in the Sustainable Development Goals called on the world "to conserve and sustainably use the oceans," 26 and in 2015, the General Assembly (GA) promoted a convention on the conservation and sustainable use of marine biological diversity of areas beyond national jurisdiction. ${ }^{127}$ The issue of bycatch can and must be dealt within the sphere of sustainable fisheries, because it is one of the main obstacles to a responsible fishery that does not put into danger the existence of marine life.

\section{Fisheries Law Response to Bycatch}

Bycatch is one of the main challenges to sustainable fisheries, because it has a negative impact on protected marine species-harming the welfare of individuals, contributing to population declines, and impeding population recovery—commonly exploited fish stocks—contributing to overfishing and hindering efforts towards population recovery—and marine habitats—bycatch of habitat-forming benthic species like corals and sponges. ${ }^{128}$ Sustainable fisheries require effective management of all sources of fishing mortality: UNCLOS clearly requests States to consider the effects of fishing on species associated with or dependent upon commercially exploited species. ${ }^{129}$ This concept is further developed in the UN Fish Stock Agreement, which calls on States to minimize the "catch of non-target species, both fish and non-fish species. .. and impacts on associated or dependent species, in particular endangered species, through measures including, to the extent practicable, the development and use of selective, environmentally safe and cost-effective fishing gear and techniques." ${ }^{130}$ Comparatively, the FAO Code of Conduct for Responsible Fisheries ${ }^{131}$ invites States to develop and apply environmentally safe and selective fishing gears and practices, minimize waste, and minimize bycatch and impact on associated or dependent species. ${ }^{132}$ The International Guidelines on Bycatch Management and Reduction of Discards were then adopted by FAO on May 22, 2012. ${ }^{133}$

Several efforts have been initially undertaken at the domestic level to address this problem, because most fish are generally caught within the 200 miles ZEE. In the United States, the Marine Mammal Protection Act—one of the strongest marine mammal conservation laws worldwide-has set a national policy with the goal of preventing an excessive decline of marine

\footnotetext{
${ }^{126}$ U.N. Sustainable Development Goals, U.N. Goal 14 (2019) https://sustainabledevelopment.un.org/sdgs (last visited May 10, 2019).

${ }^{127}$ G.A. Res. 69/292 (June 19, 2015) (creating development of an international legally-binding instrument under the United Nations Convention on the Law of the Sea on the conservation and sustainable use of marine biological diversity of areas beyond national jurisdiction); Efstathia Laina, Moving Toward a Treaty on Conservation and Sustainable Use of Ocean Resources, 46 ENVTL. POL'y \& L. 201 (2016).

${ }^{128}$ The first bilateral and multilateral efforts to limit bycatch date back to the nineteenth century and the beginning of the twentieth century. Notable examples are provided by the Treaty pertaining to the usage of the Rhine River for fishing by Switzerland and the Grand Dutch of Baden of May 18, 1887, that restricted the use of mesh sizes of nets, and the Convention for the Regulation of Mesh Sizes of Fishing Nets and the Size Limits of Fish of April 5, 1946; see 3 J.H.W. Verzijl, International LaW in Historical Perspective 210 (1970).

${ }^{129}$ United Nations Convention on the Law of the Sea art. 119, II 1, Dec. 10, 1982, 1833 U.N.T.S. 397 ("[T] ake into consideration the effects on species associated with or dependent upon harvested species with a view to maintaining or restoring populations of such associated or dependent species above levels at which their reproduction may become seriously threatened.") [hereinafter UNCLOS].

${ }^{130} I d$. art. 5.

${ }^{131}$ FAO Code of Conduct, supra note 123.

${ }^{132} I d$. at paras. 6.5-6.8. A detailed overview of the responses provided by international law to the issue of bycatch is provided by Alexander Gillespie, Wasting the Oceans: Searching for Principles to Control Bycatch in International Law, 17 INT'L J. MARine CoAstal L. 161 (2002).

${ }^{133} \mathrm{FAO}$, International Guidelines on Bycatch Management and Reduction of Discards (2011), http://www.fao. org/docrep/015/ba0022t/ba0022t00.pdf.
} 
mammal stocks through bycatch. It prohibits the intentional and unintentional capture of marine mammals.

The Marine Mammal Protection Act (MPAA) bans the use and sale of marine mammals captured in commercial fisheries. Similar legislation prohibits the sale of marine mammals in many other countries, and to this aim it requests commercial fisheries to reduce to insignificant levels incidental mortality or serious injury of marine mammals. US fisheries, in particular, must not exceed a determined threshold of their bycatch levels of marine mammals. If they do, they can be forced to replace their fishing gears or to not fish temporarily. The bycatch legal regime was reinforced in 2016 by the enactment of an innovative provision: The Final Rule to Implement Import Provisions under the Marine Mammal Protection Act, which went into effect January 1, 2017. Now, States willing to export seafood to the US, which is the world's largest seafood importer, must prove within a five-year exemption period that they do not intentionally hunt or kill marine mammals and that their bycatch mitigation strategies and laws are analogous in efficacy to those of US fisheries-comparable in effectiveness. ${ }^{134}$ This similar standard clause has the double goal of protecting both marine mammals from unsustainable bycatch and US fishermen from foreign competitors and unfair competition, because they must respect strict rules against bycatch. ${ }^{135}$ A similar measure was adopted with reference to the importation of shrimp to US: Countries wishing to export shrimp to the US must issue a certificate-which is then verified by the Fish and Wildlife Service-declaring that their methods of shrimp harvesting do not adversely cause damage to sea turtles. ${ }^{136}$

The provisions of the MMPA are complemented by the National Bycatch Reduction Strategy, whose goal it is to guide and coordinate NOAA Fisheries' efforts to reduce bycatch and bycatch mortality in support of sustainable management of fisheries and the recovery and conservation of protected species. In this regard, the Magnuson-Stevens $\mathrm{Act}^{137}$ requires the minimization of both the amount of bycatch and the mortality rate that it entails.

On the high seas, freedom of fishing is highly limited, because fishing vessels must respect the fishing quotas and fishing rules set up by Regional Fisheries Management Organizations (RFMOs). ${ }^{138}$ RFMOs' policy on bycatch is indeed crucial, because the primary mortality source of cetaceans - as well as sharks, seabirds, and sea turtles - in this zone of the sea is represented by accidental catch in purse seine and pelagic longline tuna fisheries, which are the two main gear types used to fish tuna. In fact, RFMOs have dominion over fishing management on specific sectors of the high seas - the Atlantic Ocean, Indian Ocean, and Pacific Ocean-now defined as a

\footnotetext{
${ }^{134}$ Countries with well-known bycatch problems mostly affected by the MMPA rules include Argentina, Australia, Canada, Iceland, Italy, Mexico, Norway, the Philippines, Portugal, South Africa, South Korea, Spain, and Sri Lanka. See WWF Factsheet 2018, Investigations of countries exporting seafood to US which may be subject to regulation under the MMPA bycatch rule with respect to cetaceans. http://wwf.panda.org/wwf_news/?325351/US-Cetacean-bycatch-reductionMeasures-Investigations (last visited, May 11, 2019).

${ }^{135}$ Matt Burgess \& Rob Williams, New US Seafood Rule Shows Global Trade and Conservation Can Work Together, CONVERSATION (Jan. 10, 2017), http://theconversation.com/new-us-seafood-rule-shows-global-trade-and-conservation-canwork-together-70903.

${ }^{136}$ Appellate Body Report, United States-Import Prohibition of Certain Shrimp and Shrimp Products, WTO Doc. WT/ DS58/AB/R (adopted Oct. 12, 1998).

${ }^{137}$ The Magnuson-Stevens Fishery Conservation and Management Act of 1976, 16 U.S.C. $\$ 1801$ (2018) (demonstrating the main law in the United States governing fisheries management) [hereinafter MSFCMA].

${ }^{138}$ UNCLOS recognized that freedom of fishing on the high seas, enshrined in Article 116, is no longer absolute. Therefore, fishing must be carried out under the conditions and limits established by the Convention, including general obligations to protect and preserve the marine environment-Part XII—and to conserve and manage high seas living resources-Part VII, Section 2. Indeed, "States shall cooperate with each other in the conservation and management of living resources in the areas of the high seas." UNCLOS art. 118. As a part of this cooperation, States shall adhere to regional fishery organizations. In addition, States have to establish the total allowable catch (TAC) for their fishing vessels and must adopt other conservation measures based on the best scientific evidence available to maintain or restore populations of harvested species to levels which can produce the maximum sustainable yield. Id. art. 119, para. 1.
} 
"fine-tuned mare clausum."139 Most of them deal with highly-migratory species, mainly tuna and tuna-related species, ${ }^{140}$ while others manage fish stocks by geographical area. ${ }^{141}$ They have not, however, developed specific legislation to cover the problem of bycatch.

Gilman, in this regard, has highlighted critical deficits related to the absence of appropriate measures as well as the inadequacy of current bycatch mitigation measures. ${ }^{142}$ Indeed, the main regulation gaps can be summarized as scarce reliance on gear technology approaches, implementation problems, lack of observers on board, and inadequate data collection. ${ }^{143}$ The reasons for these problems are related to the governance mechanism within RFMOs, because all decisions must be adopted through consensus. Of the current five RFMOs dealing with tuna and tunarelated species, most of them have, however, succeeded in adopting compulsory measures with the goal of mitigating bycatch of seabirds, sea turtles, sharks, and juvenile or small tunas. Still, rules concerning cetaceans remain lacking. ${ }^{.44}$

One notable exception is the Inter-American Tropical Tuna Commission (IATTC) that has promoted the International Dolphin Conservation Program (IDCP) and the 1998 Agreement on the International Dolphin Conservation Program (AIDCP). The main goal of the AIDPC is the reduction of incidental "dolphin mortalities in the tuna purse-seine fishery to levels approaching to zero[,] through the setting of annual limits" and the elimination of "dolphin mortality in this fishery, to seek ecologically sound means of capturing large yellowfin tuna not in association with dolphins." 145

AIDCP and IATCC manage the effects of international tuna purse-seine fisheries on marine mammals through the setting of annual limits of incidental dolphin mortalities ${ }^{146}$ in order to seek

\footnotetext{
${ }^{139}$ Helmut Tuerk, Reflections on the Contemporary Law of the Sea 177 (2012).

${ }^{140}$ RFMOs devoted to tuna fishing are: The International Commission for the Conservation of Atlantic Tunas (ICCAT); the Indian Ocean Tuna Commission (IOTC); the Western and Central Pacific Fisheries Commission (WCPFC); the InterAmerican Tropical Tuna Commission (IATTC); the Agreement on the International Dolphin Conservation Programme; and the Commission for the Conservation of Southern Bluefin Tuna (CCSBT).

${ }^{141}$ Among them are: North-East Atlantic Fisheries Commission (NEAFC), http://www.neafc.org/; Northwest Atlantic Fisheries Organization (NAFO) http://www.nafo.int/; North Atlantic Salmon Conservation Organization (NASCO), http://www.nasco.int/; South-East Atlantic Fisheries Organization (SEAFO), http://www.seafo.org/; South Indian Ocean Fisheries Agreement (SIOFA), https://www.apsoi.org/; South Pacific Regional Fisheries Management Organization (SPRFMO), http://www.southpacificrfmo.org/; Convention on Conservation of Antarctic Marine Living Resources (CCAMLR), http://www.ccamlr.org/; General Fisheries Commission for the Mediterranean (GFCM), http://www.gfcm. org/gfcm; and Convention on the Conservation and Management of Pollock Resources in the Central Bering Sea (CCBSP), http://www.fao.org/fishery/rfb/ccbsp/en.

${ }^{142}$ Eric L. Gilman, Bycatch Governance and Best Practice Mitigation Technology in Global Tuna Fisheries, 35 MARINE POL'Y 590 (2001).

${ }^{143}$ Michael Lodge, Managing International Fisheries: Improving Fisheries Governance by Strengthening Regional Fisheries MANAgEment Organizations (2007), https:/www.chathamhouse.org/sites/default/files/public/ Research/Energy,\%20Environment\%20and\%20Development/bpfisheries0307.pdf (summarizing RFMOs' gaps as well as reform proposals).

${ }^{144}$ For a list of measures adopted by RFMOs for stock conservation, bycatch mitigation, and monitoring, see Int'l Seafood Sustainability Found., A List of the Most Recent Measures Adopted by RFMOs for Stock Conservation, Bycatch Mitigation, and Monitoring, RFMO MGMT. DATABASE (Aug. 2017) https://iss-foundation.org/knowledge-tools/databases/rfmo-managementdatabase/.

${ }^{145}$ Agreement on the International Dolphin Conservation Program art. 1, May 15, 1998, 37 I.L.M. 1246 [hereinafter AIDCP]. The AIDPC was preceded by the 1992 La-Jolla Agreement-Agreement for the Reduction of Dolphin Mortality in the Eastern Pacific Ocean-negotiated under the auspices of IATTC and signed by the US and eleven other countries. The goal of the program envisaged by this Agreement was of "progressively reducing dolphin mortality in the Eastern Pacific Ocean fishery to levels approaching to zero.” See Philippe Cullet \& Annie Patricia Kameri-Mbote, Dolphin Bycatches in Tuna Fisheries: A Smokescreen Hiding the Real Issues? 27 OCEAN Dev. \& INT'L L. 333 (1996).

${ }^{146} \mathrm{~A}$ similar mechanism based on a threshold that must not be exceeded was also adopted by ASCOBANS at its COP 5 held in 2006 in The Netherlands. Resolution No. 5 on Incidental Take of Small Cetaceans, which has the general aim "to minimise bycatch (i.e. to ultimately reduce to zero)," establishes the threshold of bycatch that must not be crossed below the level of "unacceptable interactions," which means "to reduce bycatch to less than $1 \%$ of the best available abundance estimate."
} 
alternative means of capturing large yellowfin tunas not in association with dolphins and to ensure the long-term sustainability of tuna stocks and marine resources. ${ }^{147}$ Indeed, one of the most innovative features of the AIDCP is the establishment of a system of trade of the annual dolphin mortality limits (DMLs) which is assigned to each fishing boat. ${ }^{148}$ In few words, each vessel is allowed to reallocate the surplus of its DMLs-in exchange for some financial gain - to other vessels that do not manage to respect their limits. ${ }^{149}$

In the light of the sharp decline of fish stocks, RFMOs are now also dealing in a more incisive manner in conservation issues, rather than exclusively focusing on fisheries management. Nevertheless, fisheries management - which is also related to the economic interests of the fishing industry-is still overly focused on simply establishing catch limits on the basis of an assessment of the fish population.

Marine mammals are included within fishing management only in an incidental manner, because they often fall victim to accidental caught and gear entanglement. Most cetaceans are, however, regularly hunted in Nordic countries, as well as in Japan-through the highly controversial practice of dolphin drive hunting - and Taiwan. They are also victims of illegal fishing in Peru despite their protected status under Peruvian law.

Considering that most marine mammals are classified as endangered species, wildlife law is traditionally deemed as the most appropriate forum to deal with their conservation. In this regard, some scholars highlighted the current legal gap in conservation of marine mammals, on the one hand, and commonly exploited fish, on the other hand-some of which, like the red tuna are at the brink of extinction. In fact, in light of the low market value of their meat-at least in Western countries - and the empathy humans show towards them, marine mammals are afforded a higher level of protection than commonly exploited fish. ${ }^{150}$ Therefore, conservation policies towards fish carried out within fisheries law do not discuss their harvesting or deal with welfare issues, but simply aim their conservation at a level that would allow their exploitation.

\section{EU Fishing Policy and Bycatch Mitigation Measures}

The EU is the world's major fishing entity with about 5 million tons of fish stocks caught annually. Denmark, Spain, and the United Kingdom contribute to almost half of total catches. ${ }^{151}$ Fishing, alongside agriculture, is included amongst the concurrent competencies of EU Member States, ${ }^{152}$ while the protection of the marine environment, including the conservation and sustainable management of fishing resources within the Common Fisheries Policy (CFP), is an exclusive competence of the EU. ${ }^{153}$ The CFP "shall apply the precautionary approach to fisheries management, and shall aim to ensure that exploitation of living marine biological resources restores and maintains populations of harvested species above levels which can produce the maximum sustainable

\footnotetext{
${ }^{147}$ Consolidated Resolution on Bycatch C-04-05, IATCC (2006), https:/www.iattc.org/PDFFiles/Resolutions/IATTC/ _English/C-04-05-REV-Jun-2006-Active_Consolidated\%20bycatch\%20resolution.pdf (requiring fishermen on purse-seine vessels "to promptly release, unharmed, to the extent practicable, all sharks, billfishes, rays, dorado, and other non-target species" and, in particular, sea turtles).

${ }^{148}$ AIDCP art. 5 ; id. annex 3.

${ }^{149}$ AIDCP annex 8 (obliging vessels over a certain size operating purse-seine nets to equip themselves with "dolphin safety panels" through which dolphins can find an escape route).

${ }^{150}$ Steven R. Kellert, American Perceptions of Marine Mammals and Their Management (1999).

${ }^{151}$ See Eurostat Report, Sustainable Development in the European Union: A Statistical Glance from the Viewpoint of the UN Sustainable DeVelopment Goals 117 (2016).

${ }^{152}$ TFEU, supra note 83 , at art. 4.

${ }^{153}$ Id. art. 3; see also Regulation 1380/2013 of Dec. 11, 2013, on the Common Fisheries Policy, Amending Council Regulations 1954/2003 and 1224/2009 and Repealing Council Regulations 2371/2002 and 639/2004 and Council Decision 2004/585/EC, 2013 O.J. L (354) 22 (EU) [hereinafter Regulation 1380/2013] (culminating the fact that the CFP was under a reform process). According to Article 1(a) "the Common Fisheries Policy shall cover: the conservation of marine biological resources and the management of fisheries and fleets exploiting such resources."
} 
yield." ${ }^{154}$ The Council is responsible, according to paragraph 3 of Article 43 of the TFEU, for establishing, upon the proposal of the Commission, the total allowable catches (TACs) for all regulated fish species on the basis of available scientific advice and in accordance with the principles on sustainable fishing enshrined in Regulation (EU) No 1380/2013. ${ }^{155}$ Regulation (EU) No 1380/2013 delineates the key elements of the CFP that should be based on the principle of sustainable exploitation of marine biological resources. ${ }^{156}$ It requires that conservation measures be adopted by taking into account available scientific, technical, and economic advice.

In recent years, growing attention by EU institutions to marine mammal conservation has entailed the enactment of a set of measures strongly limiting the use of driftnets-the zero tolerance approach-in EU waters and a Regulation concerning the size of gill nets and trawls used by EU fisheries in order to avoid bycatch of marine mammals. ${ }^{157}$ These sets of rules were passed under EU fisheries law to demonstrate the growing intersection in the EU between the environment and fisheries. Indeed, fishing is one of the main factors affecting the realization of the good environmental status (GES) of the marine environment by 2020 as requested by the Seventh Environment Action Programme ( $7^{\text {th }}$ EAP). ${ }^{158}$

Driftnets are a type of fishing gear which negatively affect non-target species ${ }^{159}$ and have been heavily targeted by environmental groups as being especially indiscriminate. Indeed, driftnets spanning tens of kilometers deployed on the high sea were responsible for the killing of thousands of non-commercial and non-target species—sea turtles, dolphins, pinnipeds, cetaceans, and sea birds - and species below the minimum size for marketing. As a consequence, a worldwide environmental campaign against the use of driftnets on the high seas-which are larger than those used in territorial waters - was launched, and at the $44^{\text {th }}$ session of the General Assembly, the US, and seventeen States_-including Australia, Canada, and New Zealand-promoted a ban on driftnets on the high seas. Despite Japan's opposition calling for conclusive scientific evidence on the adverse effect of driftnets on ocean ecosystems, the GA passed two resolutions ${ }^{160}$ establishing a moratorium on "all large scale pelagic driftnet fishing." 161 In support of these resolutions, Council Regulation No. $345 / 92^{162}$ reiterated the UN ban on the use of driftnets greater than 2.5 kilometers long in European waters.

A further development is represented by Council Regulation No. 894/97-then amended by Council Regulation No. 1239/98 ${ }^{163}$ — that outlawed keeping on board and using driftnets, regardless of size, that are intended for the capture of the twenty-three most commonly exploited fishes

\footnotetext{
${ }^{154}$ Regulation $1380 / 2013$, supra note 152 , at art. 2.

${ }^{155}$ TFEU, supra note 83, at art. 43(3) ("The Council, on a proposal from the Commission, shall adopt measures on fixing prices, levies, aid and quantitative limitations and on the fixing and allocation of fishing opportunities.").

${ }^{156} \mathrm{TFEU}$, supra note 83 , at preamble.

${ }^{157}$ Richard Caddell, By-Catch Mitigation and the Protection of Cetaceans: Recent Developments in EC Law, 8 J. INT'L WiLdLIFE L. \& POL'Y 241, 248 (2005).

${ }^{158}$ Decision 1386/2013/EU of the European Parliament and of the Council of 20 November 2013 on a General Union Environment ActionProgramme to 2020 "Living well, within the limits of our planet," 2013 O.J. (L 354) 171.

${ }^{159}$ Simon P. Northridge, Driftnet Fisheries and Their Impacts on Non-Target Species: A Worldwide Review, FAO FISHERIES TECHNicAl PAPER 320 (1991).

${ }^{160}$ G.A. Res. 44/225 (Dec. 22, 1989) and G.A. Res. 45/197 (Dec. 21, 1990) (concerning large-scale pelagic driftnet fishing and its impact on the living marine resources of the world's oceans and seas). At regional level, is also worth mentioning the Convention for the Prohibition of Fishing with Long Driftnets in the South Pacific, opened for signature Nov. 24, 1989, 29 I.L.M. 1449 (1990).

${ }^{161}$ See also UNEP/CMS Resolution on Bycatch 9.18, CMS (Dec. 5, 2008), https://www.cms.int/sites/default/files/document/ Res_9_18_ByCatch_En.pdf.

${ }^{162}$ Council Regulation 345/92/EEC of Jan. 17, 1992, Amending for the Eleventh Time Regulation 3094/86 Laying Down Certain Technical Measures for the Conservation of Fishery Resources, 1992 O.J. (L 42) 15.

${ }^{163}$ Council Regulation 1239/98 of Jun. 8, 1998, Amending Regulation 894/97 Laying Down Certain Technical Measures for the Conservation of Fishery Resources, 1998 O.J. (L 171) 1 (EC).
} 
listed in Annex VIII, ${ }^{164}$ including: bluefin tuna; bigeye tuna; atlantic bonito (Sarda sarda); marlins; swordfishes; dolphinfishes (Coryphoena spp.); some species of sharks-Hexanchus griseus, Cetorhinus maximus, Alopiidae, Carcharhinidae, Sphymidae, Isuridae, and Lamnidae; and cephalopods. ${ }^{165}$ For these species listed in Annex VIII, there is also a ban on landing: Paragraph two of Article $11 b$ affirms that "it is prohibited to land species listed in Annex VIII which have been caught in drift-nets." ${ }^{166}$ This Regulation was last amended by Regulation No. 809/2007, ${ }^{167}$ which introduces a definition of driftnets, ${ }^{168}$ and reiterates the ban on driftnets in EU waters, now including the Baltic Sea after the admission of Poland and the Baltic Republics in 2004: "No vessel may keep on board, or use for fishing, one or more drift nets whose individual or total length is more than [2.5 kilometers]."169

The Baltic Sea community states then favored the adoption of a regulation for the protection of small cetaceans, notably the harbor porpoise-a cetacean species resident in the Baltic Sea. Indeed, long line fleets of Baltic States unaffected by the blanket prohibition of Regulation No. 1239/98 had severely threatened the survival of the harbor porpoise. Regulation 812/2004/EC on measures concerning incidental catches of cetaceans in fisheries - so called Incidental Catches Regulation ${ }^{170}$ has established a set of measures whose goal is that of "mitigating incidental catches of cetaceans by fishing vessels."

This Regulation introduces innovative mitigation measures, such as the mandatory use of acoustic deterrent devices for fishing vessels of twelve meters or more in overall length ${ }^{171}$ — the only exception being fishing operations carried out for research purposes and with the particular aim of developing new technical measures to reduce the incidental capture or killing of cetaceans. ${ }^{172}$ Furthermore, technical measures concerning the size and typology of gears-particularly, bottom-set gillnets or entangling nets and drift-nets defined in Annex I in particular areas on the basis of the sub-areas and divisions of FAO fishing area, notably the Baltic Sea-have been banned.

As to monitoring, apart from the reporting duty upon Member States, ${ }^{173}$ ships with an overall length of fifteen meters or more must retain on board an independent observer in charge of

\footnotetext{
${ }^{164}$ Council Regulation 894/97 of Apr. 29, 1997, Laying Down Certain Technical Measures for the Conservation of Fishery Resources, art. 11, 1997 O.J. (L 132) 1 (EC).

${ }^{165}$ Council Regulation 2187/2005 of Dec. 21, 20015 for the Conservation of Fishery Resources Through Technical Measures in the Baltic Sea, the Belts and the Sound, Amending Regulation 1434/98 and Repealing Regulation 88/98, 2005 O.J. (L 349) 1 (EC).

${ }^{166} \mathrm{It}$ is also worth mentioning that the fifth recital mentioned the former Article 130 of the TEU dealing with environment, stating, inter alia, that the Community policy shall be inspired by the principles of precaution and prevention. Therefore, the necessity to manage fisheries in a manner coherent with European environmental standards has been envisaged. See RONÁN J. Long \& Peter A. Curran, Enforcing the Common Fisheries Policy 300 (2000).

${ }^{167}$ Council Regulation 809/2007 of June 28, 2007, Amending Regulations 894/97, 812/2004 and 2187/2005 as Concerns Drift Nets, 2007 O.J. (L 182) 1 (EC) [hereinafter Council Regulation 809/2007].

${ }^{168}$ Council Regulation 809/2007 art. 1 states:

Drift net means: any gillnet held on the sea surface or at a certain distance below it by floating devices, drifting with the current, either independently or with the boat to which it may be attached. It may be equipped with devices aiming to stabilise the net or to limit its drift.

${ }^{170}$ Council Regulation 812/2004 of Apr. 26, 2004, Laying Down Measures Concerning Incidental Catches of Cetaceans in Fisheries and Amending Regulation 88/98, 2004 O.J. (L 150) 12 (EC) [hereinafter Council Regulation 812/2004]; Regulation No. 812 was partially amended by Regulation 597/2014 of the European Parliament and of the Council of Apr. 16, 2014, Amending Council Regulation 812/2004 Laying Down Measures Concerning Incidental Catches of Cetaceans in Fisheries, 2014 O.J. (L 173) 62) (EU).

${ }^{171}$ Council Regulation 812/2004, supra note 169, at art. 2, paras. 1, 2.

${ }^{172} I d$. art. 2, para 3.

${ }^{173}$ Habitats Directive art. 6. Reporting duty upon EU Member States, as already envisaged by Habitat Directive art. 12. Art. 12 states:

Member States shall establish a system to monitor the incidental capture and killing of the animal species listed in Annex IV (a). In the light of the information gathered, Member States shall take further research or conservation measures as required to ensure that incidental capture and killing does not have a significant impact on the species concerned.
} 
reporting incidental catch of cetaceans and collecting statistical data. ${ }^{174}$ The US has developed a similar mechanism management scheme aimed at categorizing fishing vessels according to their likelihood of bycatching marine mammals during their fishing activity. In particular, if a fishing vessel is classified as having a high probability of bycatching marine mammals, it must register each bycatch and it must host on board an independent observer to estimate bycatch rates. ${ }^{175}$

Also, the EU Biodiversity Strategy 2020 contains a specific action related to bycatch. Action 14, as implementing tool of Target 4-"Make fishing more sustainable and seas healthier"-states that the EU will "[r]educe the impact of fisheries by gradually getting rid of discards and avoiding by-catch."

Despite the efforts by the EU in addressing bycatch, the European Commission highlighted the shortcomings in the current legislation in a review of Regulation n. 812 carried out in $2011 .{ }^{176}$ The two reports showed a non-uniform implementation of Regulation No. 812 by EU Member States, with some of them making genuine efforts towards cetaceans conservation and others not considering bycatch mitigation as a top priority. Furthermore, no action has been taken by the EU against reluctant States. It is clear that the implementation of Regulation No. 812 needs to be improved, focusing on the reduction of bycatch and more effective monitoring, and that more efforts should be requested in order to reduce bycatch in a significant manner. ${ }^{177}$

In conclusion, a threefold legal basis of EU law on the conservation of marine mammals can be highlighted. Indeed, bycatch of marine mammals falls within EU fisheries policy, the ban on the import of whale meat and whale products within the environmental policy, and seal protection, at least partially, under Title II of the TFEU-particularly, Article 13 of the TFEU. Because fisheries and the environment are now considered as strictly interrelated issues in the light of the integration principle, it is evident that welfare issues can also form part of the wider EU environmental policy.

\section{The Way Forward}

Current legal efforts towards the conservation of marine mammals are remarkable, both in the field of wildlife law and fisheries law. There are, of course, shortcomings in the current legal regime related to the fact that small cetaceans do not fall within the competence of the IWC, and the continuous struggle between pro-whaling and anti-whaling countries hinders any reform of the current conservation mechanism. The same division is present with regard to seals, small cetaceans, other marine mammals, and fish-like sharks. Some States or groups of States pay more attention to conservation issues, while others justify their hunting or fishing policy, relying on various reasons like market value of certain products, protection of indigenous rights, or delicacy of a particular product, as is the case with whale meat.

With regard to cetaceans which have a high vulnerability and are therefore especially threatened, several reform proposals have surfaced to guarantee their conservation and avoid their extinction. They range from a global ban on hunting of all cetaceans to a more holistic-orientated approach, which would imply not only dealing with fishing, but also with all the modern threats to marine mammal conservation. Some scholars even put forward a sustainable management model

\footnotetext{
${ }^{174}$ Council Regulation $812 / 2004$, supra note 169 , art. 5 .

${ }^{175}$ The Marine Mammal Protection Act establishes further specific technical measures addressed to US fisheries to protect cetaceans from bycatch. The respect of similar technical measures to reduce bycatch are also requested to foreign fisheries that intend to export fish products towards the United States. Rob Williams, Matthew G. Burgess, Erin Ashe, Steven D. Gaines \& Randall R. Reeves, U.S. Seafood Import Restriction Presents Opportunity and Risk, 354 SCIENCE 1372 (2016).

${ }^{176}$ Communication from the Commission to the European Parliament and the Council - Cetacean Incidental Catches in Fisheries: Report on the Implementation of Certain Provisions of Council Regulation (EC) No 812/2004 and on a Scientific Assessment of the Effects of Using in Particular Gillnets, Trammel Nets and Entangling Nets on Cetaceans in the Baltic Sea as Requested Through Council Regulation (EC) No 2187/2005, COM (2009) 368 final (July 16, 2009).

${ }^{177}$ Sarah Dolman et al., Towards an EU Action Plan on Cetacean Bycatch, 72 MARINE POL'y. 67 (2016).
} 
that should include some consumptive uses of whales, including opening a lift of the moratorium, in order to persuade pro-whaling countries to consent to a reform. ${ }^{178}$

An adequate conservation policy of marine mammals cannot be untied from a reform of fisheries law. The global fisheries governance mechanism needs to be improved, recognizing that the fishing industry and, in particular, the large-scale capture and farming of fish, is having devastating effects on the marine life-both on targeted and non-targeted species. In particular, fisheries law, although not directly tailored to marine mammal conservation, is crucial for their protection, because bycatch is the main threat to marine mammal conservation. Fisheries-based proposals for mitigating bycatch call for the institution of more marine protected areas that would cover $20 \%$ of the world oceans-especially areas within the migration routes of cetaceans ${ }^{179}$ - seasonal closures, ${ }^{180}$ a wide use of acoustic alarms or pingers, and in particular-as suggested by a CMS technical report-the development of alternative gear to replace current fishing methods such as gillnets. ${ }^{181}$ Mitigation of the devastating effects of bycatch must be the ultimate goal of these fishing policies, while an effective reduction would require more drastic measures, such as a strong limitation of individual fishing quotas. Nevertheless, the inertia of governments and the fishing industry - their unwillingness to accept the reduction of their fishing efforts and to improve their actions against IUU and bycatch — is the main obstacle to further legal developments. The US represents notable exemptions in the new seafood rule of 2016 that calls for fisheries exporting seafood to the US to adopt conservations standards-including those that cover the issue of bycatch-comparable to those required for US fisheries. This new legislation aims to harmonize bycatch standards to the higher level currently represented by the US and, accordingly, can also be considered as the golden rule for future EU legislation.

\section{Concluding Remarks}

Marine mammals and, in particular, cetaceans, are facing serious threats due to unsustainable fishing - overfishing, bycatch, and illegal and unreported fishing - and habitat depletion-the destruction of maritime habitats due to invasive human activities, climate change, and uncontrolled tourism. Incidental capture in fishing gear is only one threat to their survival, but it is nevertheless one that most significantly affects their welfare due to death by asphyxiation resulting from entanglement in fishing gear, the its major negative impact on conservation in general.

The present Article highlighted the two levels of protection of marine mammals. The first, direct protection, is represented by wildlife law banning direct threats_-such hunting, skinning, trading. The second, indirect protection, is represented by fisheries law-addressing indirect threats to marine mammals when they are not the primary target of fisheries.

In this framework, measures that only ban or prohibit practices directly targeting marine mammals-hunting, whaling, skinning, and importing meat products-have drastically decreased their mortality rate and have, in several cases, allowed the most threatened populations to recover. ${ }^{182}$ Indeed, these measures have the goal of helping threatened species to regain

\footnotetext{
${ }^{178}$ Tara Jordan, Revising the International Convention on the Regulation of Whaling: A Proposal to End the Stalemate Within the International Whaling Commission, 29 WIS. INT'L. L.J. 833 (2012).

${ }^{179}$ Andrew M. Gormley, Elisabeth Slooten, Steve Dawson, Richard J. Barker, Will Rayment, Sam du Fresne, Stefan Bräger, First evidence that marine protected areas can work for marine mammals, 49 J APPL ECOL 474 (2012).

${ }^{180}$ In the US, NOAA introduced a seasonal closure of fisheries in the Massachusetts Restricted Area during the period of presence in that zone of the North Atlantic right whale, whose populations steadily grew in response to the ban on fishing. National Oceanic and Atmospheric Administration, Atlantic Large Whale Take Reduction Plan's Massachusetts Trap/ Pot Restricted Area and the Great South Channel Trap/Pot Restricted Area, https://www.fisheries.noaa.gov/action/atlanticlarge-whale-take-reduction-plans-massachusetts-trap-pot-restricted-area-and-great (Last visited, May 11, 2019).

${ }^{181}$ LEAPER \& CALDERAN, supra note 7.

${ }^{182}$ Anna M. Magera et al., Recovery Trends in Marine Mammal Populations, 8 PLOS ONE 1 (2013) (explaining that the banning policy pursued by the IWC has reduced whale hunting dramatically and recovered most of the exploited species).
} 
pre-exploitation population levels. It is well known, however, that the great majority of whale, dolphin, and seal mortality is due to incidental capture in high-seas pelagic longlines, gillnets, and purse-seine fisheries that primarily target tuna and tuna-like species. Therefore, classical conservation measures must be necessarily complemented by mitigation measures against bycatch. Recent acts against bycatch, such as the new US seafood rule, are notable examples of progress. But, these are not a definitive solution. A definitive solution can only be found in an adequate interplay between wildlife law and fisheries law. In fact, it is clear from the foregoing analysis that the current regime on marine mammal conservation has not evolved holistically and remains overly fragmented. This situation is further compounded by different legal approaches at domestic and regional levels. Some countries and regional organizations-like Australia, the United States, and the European Union-have adopted specific measures against bycatch. Others, especially in developing countries, lack any policy on this problem. Given the migratory nature of many cetaceans, this absence of uniformity might jeopardize conservation efforts. Accordingly, wildlife protection rules and fisheries rules can, and should, support themselves in a normative interplay that determines their mutual enhancement. For instance, the CITES regime-with 183 Parties to the Convention and therefore an almost global reach—could be improved by also listing commercially-exploited fish species that are already targeted by bycatch measures that have been adopted at the domestic or regional level. At the same time RFMOs and States should adopt conservation measures against bycatch that captures fish species protected by CITES. Through these sets of measures cetaceans could gain benefit.

A further step would require including considerations on welfare in conservation approaches, with particular attention to marine mammals due to their cognitive capacities, as there is still a relatively poor understanding of the stress and pain related to the violent death that marine species experiences during fishing operations. ${ }^{183}$ In this sense, animal or fish welfare can be considered as leverage in order to prohibit certain fishing or hunting practices or to completely ban the hunt of some marine mammal species. This is exactly what happened with EU Regulation No. 1007 (2009), which-beginning with welfare concerns over the cruel practice of skinning seals that are still alive-has prohibited de facto seal hunting within EU countries.

In particular, the single-species approach that has jeopardized the level of protection and geographical application of rules must be overcome. Indeed, all marine mammals-irrespective of their conservation status and scientific classification-deserve full protection, which, in light of their high level of consciousness, means a ban of all forms of hunting and trading. In conclusion, conservation policies should not consider marine mammals as harvestable commodities like other living marine species—sustainable conservation-but as living beings who deserve conservation for the sake of preservation from extinction.

A practical solution that goes beyond the "dream" to actually propose a shift in cetacean policies is already included in the Florianopolis Declaration of 2018, which considers whaling as no longer being a necessary activity and puts forward the idea of changing the role of the IWC from an organization focused on the management of existing whale stocks to a conservation body. Yet, what would need to happen for all countries to come to the table and reach this consensus is not yet clear, in light of the permanent division between the pro- and anti-whaling blocks worsened by Japan's decision to leave the IWC.

\footnotetext{
${ }^{183}$ Vassili Papastavrou, Russell Leaper \& David Lavigne, Why Management Decisions Involving Marine Mammals Should Include Animal Welfare, 79 MARINE POL'Y. 19 (2017).
}

Cite this article: Pavone IR (2019). Is Banning Enough? The Intricacy Inherent to Marine Mammal Conservation. German Law Journal 20, 587-613. https://doi.org/10.1017/glj.2019.52 